\title{
COMPOSITE AND DIACHRONOUS STRATIGRAPHIC SURFACES IN LOW-GRADIENT, TRANSITIONAL SETTINGS: THE J-3 "UNCONFORMITY" AND THE CURTIS FORMATION, EAST-CENTRAL UTAH, U.S.A.
}

\author{
VALENTIN ZUCHUAT, ${ }^{1}$ IVAR MIDTKANDAL,,${ }^{1}$ MIQUEL POYATOS-MORÉ, ${ }^{1}$ SIGRID DA COSTA, ${ }^{1}$ HANNAH LOUISE BROOKS, ${ }^{2}$ \\ KRISTINE HALVORSEN, ${ }^{1}$ NATHAN COTE, ${ }^{3}$ ANJA SUNDAL, ${ }^{1}$ AND ALVAR BRAATHEN ${ }^{1}$ \\ ${ }^{1}$ Department of Geosciences, University of Oslo, Sem Scelands Vei 1, Oslo 0371, Norway \\ ${ }^{2}$ Department of Earth Sciences, Chiba University, 1 Yayoichō, Inage-ku, Chiba 263-0022, Japan \\ ${ }^{3}$ Natural and Environmental Sciences Department, Western Colorado University, 600 North Adams Street, Gunnison, Colorado 81231, U.S.A. \\ e-mail:valentin.zuchuat@geo.uio.no
}

\begin{abstract}
Unconformities, by definition, correspond to erosional or nondepositional surfaces, which separate older strata below, from younger rocks above, encapsulating significant time gaps. However, recent studies have highlighted the composite nature of some unconformities, as well as their heterochronous and diachronous character, which challenge the use of such a definition in a four-dimensional dynamic environment. The J-3 Unconformity, separating the Middle Jurassic Entrada Sandstone from the Upper Jurassic Curtis Formation (and laterally equivalent units) in east-central Utah (USA), is laterally variable, generated by either erosion-related processes such as eolian deflation, and water-induced erosion, or by deformational processes. The J-3 Unconformity is a composite surface, formed by numerous processes that interacted and overlapped spatially and temporally. This study therefore demonstrates the heterochronous, diachronous, and non-unique nature of this surface interpreted as unconformity, where one process can be represented by varying expressions in the stratigraphic record, and conversely many processes may result in the same stratigraphic expression.
\end{abstract}

The composite flooding-ravinement surface separating the two depositional systems in this study is time-transgressive. Consequently, the regionally extensive, composite, heterochronous, and diachronous $\mathrm{J}-3$ Unconformity does not match with the classic unconformity definition, in which an unconformity universally separates older from younger strata basin wide. This study discusses a revised definition, focusing on processes and associated environmental changes, while abandoning the time-barrier aspect. This investigation highlights common misunderstandings within the subseismic complex character of major stratigraphic bounding surfaces, especially while conducting subsurface analyses, which may lead to inaccurate timing and sediment budget predictions, and ultimately have strong implications for basin evolution and reservoir models.

Stratigraphic surfaces and the units they bound have been of interest for scientists for nearly three hundred and fifty years (Steno 1669). Hutton (1788) first described his iconic Siccar Point angular unconformity, noting that the overlying Devonian Old Red Sandstone contained fragments of the underlying rocks at its base, implying that those strata were eroded and reworked before the deposition of the overburden (Shanmungam 1988). This added an ontological dimension of (missing) time to these geological surfaces, which Blackwelder (1909) called unconformities. This time dimension is a key consideration when reconstructing the dynamics of sedimentary basins (Blackwelder 1909; Barrell 1917; Wheeler 1958; Shanmugam 1988; Miall 2016, references therein). Mitchum et al. (1977) defined unconformities as a "surface of erosion or nondeposition that separates younger strata from older rocks and represents a significant hiatus" (p. 56), thus acting as a time barrier, and used as a sequence boundary (Van Wagoner et al. 1990). The spatial scale at which this definition is applicable is, however, not specifically mentioned.

The study of unconformities offers insights into landscape-changing processes, as well as their interactions in a dynamic and constantly evolving depositional system (Kyrkjebø et al. 2004; Holbrook and Bhattacharya 2012; Miall 2016; Gani 2017; Zuchuat et al. 2018, 2019). Thus, the original definition was challenged by recent works showing that subaerial unconformities are not singular bypass surfaces (Holbrook and Bhattacharya 2012; Blum et al. 2013), and Gani (2017) argued that Steno's law of superposition is valid only in a one-dimensional system. When looking at a fluvio-deltaic system at a regional scale, subaerial unconformities occur as composite, multi-phase fluvial scours and interfluve exposed surfaces that do not necessarily separate older sediments below from younger sediments above (Holbrook and Bhattacharya 2012; Van Yperen et al. 2019). Kyrkjebø et al. (2004) also demonstrated the seismic-scale, heterochronous (heterochronous is used in this manuscript as "at different times," not to be confused with diachronous, which means "through time" or "timetransgressive.") nature of the Norwegian North Sea regional Base Cretaceous Unconformity (Fig. 1). This unconformity displays a multiepisodic amalgamation of several local to regional erosional surfaces, and should therefore be referred to as the North Sea Unconformity Complex (Kyrkjebø et al. 2004). The analysis of unconformities can therefore be regarded as valuable and complementary to the study of the sedimentary succession (Leszczyński and Nemec 2015). Moreover, understanding the development of such complex bounding surfaces can also help to identify the system's sedimentary response, as demonstrated by Al-Hinaai and Redfern (2014), who showed how the Knox Unconformity's relief 


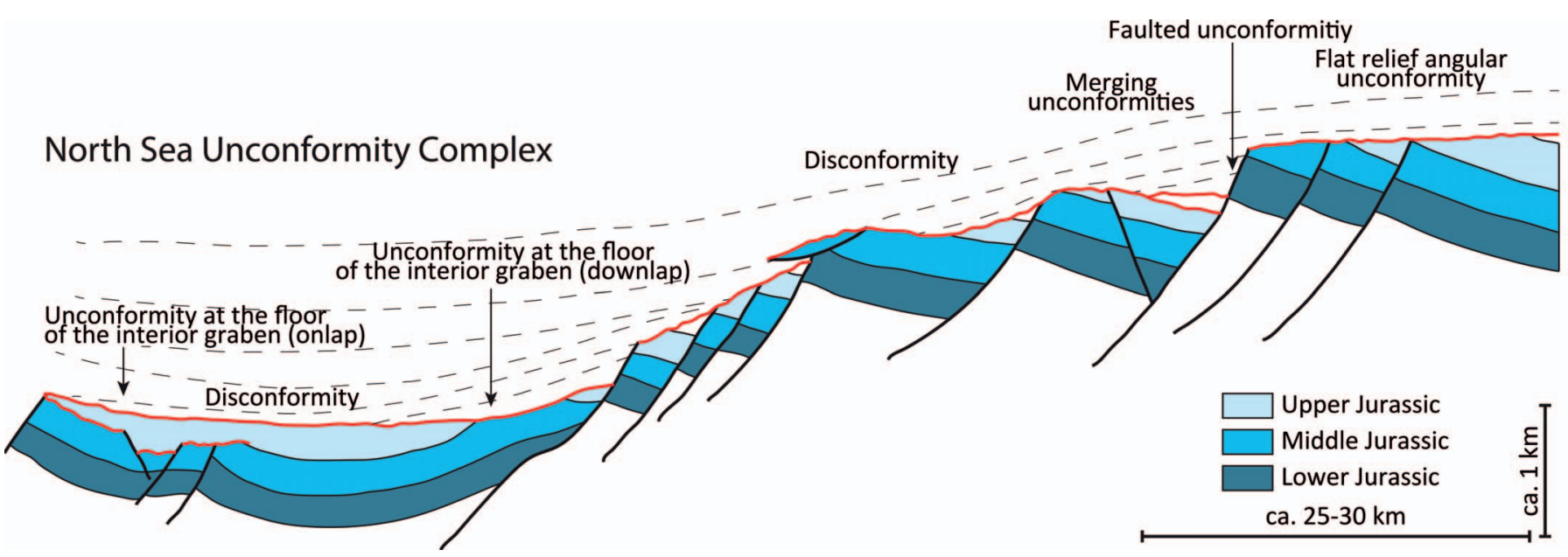

FIG. 1.-Scheme of the North Sea Unconformity Complex, illustrating the concept of regional composite unconformity (modified from Kyrkjebø et al. 2004).

influenced the spatial distribution of "postunconformity carbonates" in a passive-margin to convergent-margin transition. This was also discussed by Sattler et al. (2005), who demonstrated the spatio-temporal intricacy of processes involved in the shaping of "discontinuity surfaces" on carbonate platforms, and Miall (2016) and Gani (2017), who highlighted the intricate multi-scale nature of the temporal dimension defining any unconformityimpacted by an interplay of seconds to millennia-lasting to My-scale processes - independent of the environmental and basinal setting considered.

Pipiringos and O'Sullivan (1978) defined ten regional unconformities in the Mesozoic Western Interior succession in North America, referred to as Tr-1 to Tr-4, J-0 to J-5, and K-0 (Tr: Triassic; J: Jurassic; K: Cretaceous). Blakey (1994, 2019), Bjerrum and Dorsey (1995), and Miall (2016) argued that most are angular unconformities caused by regional tectonics and eustatic variations, and that the time gap encapsulated in each of these sedimentary breaks approaches $10^{6}$ years. However, major climatic shifts also had an impact on the development of unconformities, as illustrated by the Tr-3 Unconformity, which delimits the arid deposits and steep-sided canyons of the Moenkopi Formation from the overlying humid environment and perennial drainage systems of the Chinle Formation (Miall 2016; Blakey 2019).

This study focuses on Pipiringos and O'Sullivan's (1978) J-3 Unconformity in east-central Utah (Fig. 2), which separates the Middle Jurassic, continental Entrada Sandstone from the Upper Jurassic, shallowmarine Curtis Formation (Pipiringos and O'Sullivan 1978; Wilcox and Currie 2008; Zuchuat et al. 2018, 2019). By documenting the J-3 subseismic relief expression, its spatial distribution, amplitude, and wavelength, this work identifies local and regional processes implicated in the development of this unconformity. Understanding these processes may allow the reconstruction of this and other similar bounding surfaces, and the development of a relative timing for the mechanisms involved and their relations to underlying and overlying stratigraphy. A better comprehension of the complex nature and development of unconformities at a sub-seismic scale will improve the overall knowledge of basin dynamics regionally, and strengthen subsurface interpretations and resulting basin evolution models.

\section{GEOLOGICAL SETTING}

\section{Tectonostratigraphy}

The Entrada Sandstone and the overlying Curtis Formation belong to the Middle to Upper Jurassic San Rafael Group (Fig. 2C; Gilluly and Reeside 1928; Pipiringos and O’Sullivan 1978; Peterson and Pipiringos 1979; Anderson and Lucas 1994; Sprinkel et al. 2011). This succession formed in a retroarc foreland basin in the SSW-NNE-oriented Utah-Idaho Trough (Fig. 2B; Anderson and Lucas 1994; Brenner and Peterson 1994; Peterson 1994; Bjerrum and Dorsey 1995; Thormann 2011). The basin developed as a result of the Middle Jurassic Elko Orogeny, coupled with the Middle Jurassic to Lower Cretaceous Nevadan Orogeny (Hintze and Kowallis 2009; Thorman 2011; Dickinson 2018). The Lower Cretaceous to Paleogene Sevier and Laramide orogenies contributed to the deformation of strata, featuring basement-rooted monoclines, akin to the San Rafael Swell (Fig. 2; Bump and Davis 2003; Yonkee and Weil 2015).

\section{Entrada Sandstone}

During the Callovian, the retreating Sundance Sea was replaced by arid continental conditions, resulting in deposition of the Entrada Sandstone conformably over the shallow-marine Carmel Formation (Fig. 2C; Gilluly and Reeside 1928; Peterson 1994; Hintze and Kowallis 2009). The Entrada Sandstone consists of two units: (i) eolian dunes and finer-grained interdune deposits of the Slick Rock Member, and (ii) overlying and coeval marginal marine sediments associated with the earthy facies (informal nomenclature; Fig. 2; Gilluly and Reeside 1928; Imlay 1952; Peterson 1988; Caputo and Pryor 1991; Dickinson and Gehrels 2009, 2010; Doelling et al. 2015). The formation thickens westwards to the Utah-Idaho Trough and northwards to the Sundance Seaway (Witkind 1988; Crabaugh and Kocurek 1993; CarrCrabaugh and Kocurek 1998; Mountney 2012; Doelling et al. 2015). The Entrada Sandstone principally consists of recycled sediments from the Appalachian Mountains (Dickinson and Gehrels 2009, 2010), and comprises four construction-destruction sequences (sensu Mountney 2006) bounded by supersurfaces related to regional fluctuations of the paleo-water table and/or sea-level variations (Carr-Crabaugh and Kocurek 1998; Mountney 2012). The top of the Entrada Sandstone is truncated by the J-3 Unconformity (Pipiringos and O'Sullivan 1978), the focus of this study. They described "an inferred relief of as much as $14 \mathrm{~m}$ in about $3 \mathrm{~km}$ " (Pipiringos and O'Sullivan 1978, p. 23) north of the San Rafael Swell, although they did not discuss the processes involved in the creation of this relief. Eschner and Kocurek (1988) differentiated between inherited mellow relief (up to $3 \mathrm{~m}$ ) reflecting paleodune remains, and steep and deep erosional relief (up to $7 \mathrm{~m}$ ) sculpted by tidal currents and mass flows. Caputo and Pryor (1991) reported a relief of 0.3 to $0.9 \mathrm{~m}$, arguing that "marine currents reworked material along the J-3 Unconformity" (p. 23). Peterson (1994) wrote that "the surface appears to be a simple transgressive erosion surface that formed when Curtis seas advanced" (p. 261), arguing that the eoliandestructive episode(s) was "related to local tectonics and was not related to eustatic processes" (p. 262). 

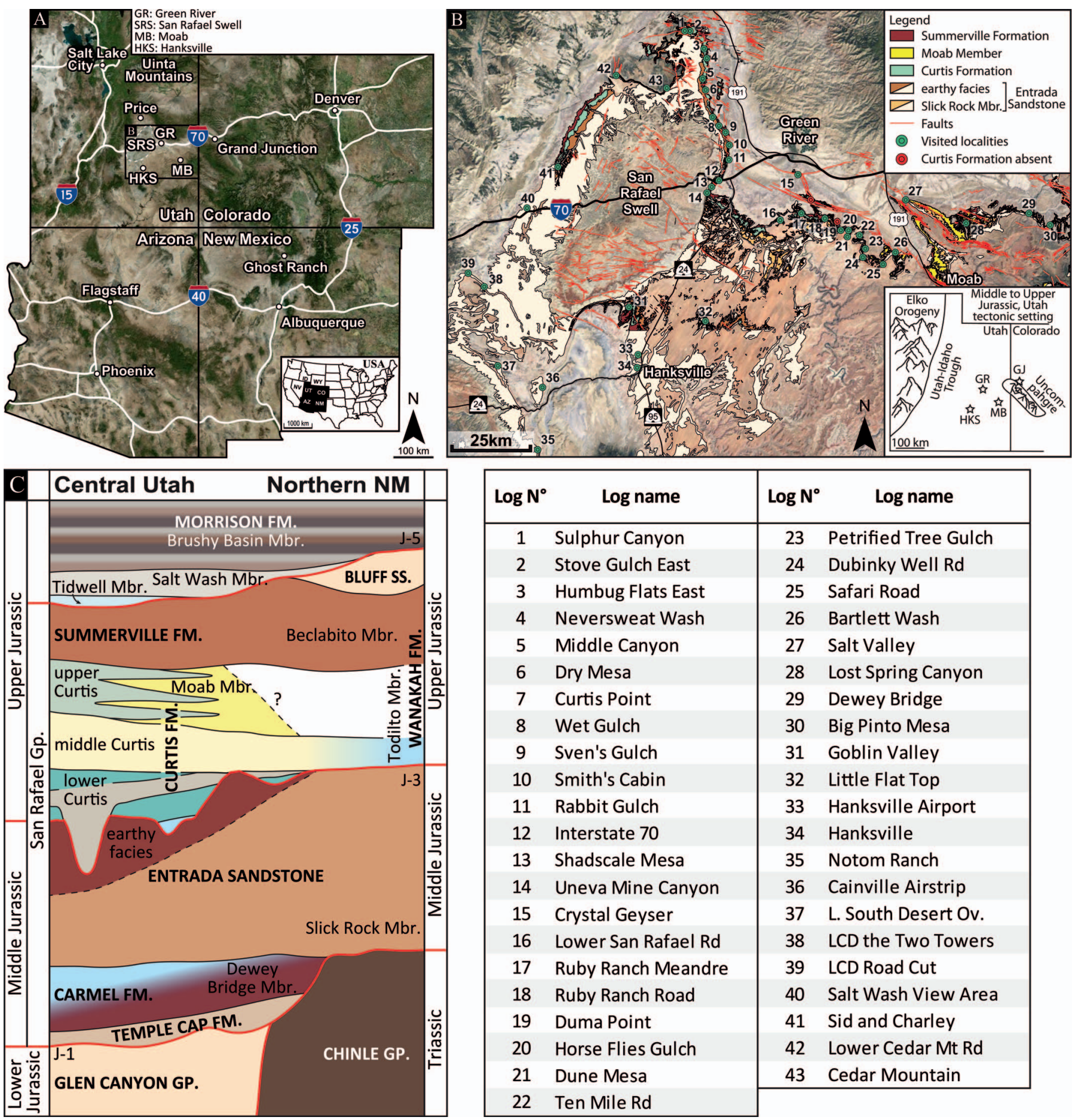

\begin{tabular}{|c|rl|l|}
\hline \multirow{2}{*}{ Log N } & \multicolumn{1}{|c|}{ Log name } & Log N & \multicolumn{1}{c|}{ Log name } \\
\hline 1 & Sulphur Canyon & 23 & Petrified Tree Gulch \\
2 & Stove Gulch East & 24 & Dubinky Well Rd \\
3 & Humbug Flats East & 25 & Safari Road \\
4 & Neversweat Wash & 26 & Bartlett Wash \\
5 & Middle Canyon & 27 & Salt Valley \\
6 & Dry Mesa & 28 & Lost Spring Canyon \\
7 & Curtis Point & 29 & Dewey Bridge \\
8 & Wet Gulch & 30 & Big Pinto Mesa \\
9 & Sven's Gulch & 31 & Goblin Valley \\
10 & Smith's Cabin & 32 & Little Flat Top \\
11 & Rabbit Gulch & 33 & Hanksville Airport \\
12 & Interstate 70 & 34 & Hanksville \\
13 & Shadscale Mesa & 35 & Notom Ranch \\
14 & Uneva Mine Canyon & 36 & Cainville Airstrip \\
15 & Crystal Geyser & 37 & L. South Desert Ov. \\
16 & Lower San Rafael Rd & 38 & LCD the Two Towers \\
17 & Ruby Ranch Meandre & 39 & LCD Road Cut \\
18 & Ruby Ranch Road & 40 & Salt Wash View Area \\
19 & Duma Point & 41 & Sid and Charley \\
20 & Horse Flies Gulch & 42 & Lower Cedar Mt Rd \\
21 & Dune Mesa & 43 & Cedar Mountain \\
\cline { 2 - 3 } 22 & Ten Mile Rd & & \\
\hline & & & \\
\cline { 2 - 3 } & & &
\end{tabular}

FIG. 2.-A, B) Maps of the study area. Green dots represent visited localities where the Curtis Formation crops out; red dots illustrate its absence. Each code number on the

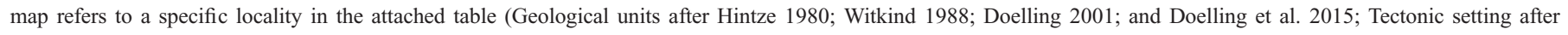
Heyman 1983; Thorman 2011; satellite pictures (CGoogle Earth). C) Schematic stratigraphic column showing a correlation between the San Rafael Swell area, east-central Utah, and Ghost Ranch, in northern New Mexico (Doelling 2001; Doelling et al. 2015; Kocurek et al. 2018; Zuchuat et al. 2018, 2019).

\section{Curtis Formation}

The lower Oxfordian Curtis Formation, consisting of shallow-marine, tidally influenced deposits, overlies the Entrada Sandstone, and was defined along the NE margin of the San Rafael Swell (Fig. 2; Gilluly and Reeside 1928; Kreisa and Moiola 1986; Caputo and Pryor 1991; Wilcox and Currie 2008; Ogg et al. 2016; Zuchuat et al. 2018). This glauconitic and chlorite-rich sedimentary unit is characterized by a green to white color, strongly contrasting with the underlying rusty red Entrada Sandstone (Gilluly and Reeside 1928; Caputo and Pryor 1991; Peterson 1994). As the Elko Orogeny foredeep accommodation decreased at the end of the Middle Jurassic (Thorman 2011), the Curtis sea covered a gently dipping, shallow 
epicontinental basin (Zuchuat et al. 2018, 2019). Due to the enclosed and fluvially starved basin configuration, the sediment supply is unconstrained, although polycrystalline quartz grains in some conglomerates imply an extrabasinal source (Zuchuat et al. 2018, 2019). The Curtis Formation thins toward the south and the east, forming a 30 to $80 \mathrm{~m}$ thickness variation along the San Rafael Swell (Fig. 2; Gilluly and Reeside 1928; Caputo and Pryor 1991; Peterson 1994; Thorman 2011; Anderson 2015). The formation is informally subdivided into the lower, middle, and upper Curtis (Zuchuat et al. 2018). The lateral equivalent of the upper Curtis deposits corresponds to the eolian Moab Member, and consists of five eolian sequences, linked to allocyclicly driven variations in relative base level and climate (Fig. 2; Caputo and Pryor 1991; Peterson 1994; Doelling 2001; Zuchuat et al. 2019).

The Curtis Formation is conformably overlain by the dark brown, hypersaline sabkha deposits of the Summerville Formation (Fig. 2; Gilluly and Reeside 1928; Caputo and Pryor 1991; Peterson 1994; Lucas 2014). However, the Summerville Formation also co-existed with the Curtis Formation as a coeval coastal plain in neighboring regions (Zuchuat et al. 2018, 2019). The Summerville Formation is capped by the J-5 Unconformity (Fig. 2C; Pipiringos and O’Sullivan 1978).

\section{DATA AND METHODS}

The dataset compiled to investigate the J-3 Unconformity comprises: (i) traditional sedimentary and structural data acquired through logging of forty-three localities (Fig. 2); (ii) photographs, including classic camera images, pictures taken with an unmanned aerial vehicle $\left(\mathrm{UAV} ; \mathrm{DJI}^{\odot}\right.$ Phantom 4), as well as satellite images from Google Earth $^{\odot}$ and Microsoft Bing Map ${ }^{\odot}$ engines; and (iii) paleocurrent indicators and other relevant structural information. In order to analyze the multi-scale sedimentary architecture of the succession, Structure-from-Motion (SfM) photogrammetry methods (after Westoby and others 2012) were used to generate three-dimensional (3D) virtual outcrops for selected localities. Photogrammetric virtual outcrop models were generated in PhotoScan Pro ${ }^{\odot}$ (Agisoft LLC, St. Petersburg, Russia). Virtual outcrop analysis was conducted in in Lime $^{\odot}$ software developed by the Virtual Outcrop Geology VOG group from Bergen and Aberdeen universities (Bonaventura et al. 2017; Buckley et al. 2017). The J-3 Unconformity was characterized in terms of relief amplitude, wavelength, visual appearance, and bounding sedimentary units at each locality. Collectively, the data is applied to determine which processes were involved in the J-3 Unconformity genesis, and to discuss both their spatial and temporal distribution.

\section{SEDIMENTOLOGY}

The sedimentological analysis of the Curtis Formation is based on Zuchuat et al. (2018). The facies association (FA) scheme is detailed in Table 1, with each FA illustrated in Figure 3. Figure 4 displays the N-S architecture along the northeastern margin of the San Rafael Swell (Fig. 2). Above the eolian and paralic deposits of the Entrada Sandstone (FA1; Fig. 3A, B), shallow-marine upper shoreface (FA 2), subtidal (FA 3), and subtidal to supratidal (FA 4) deposits form the informal lower Curtis (Figs. 3C-F, 4; Zuchuat et al. 2018), which consists of three parasequences sensu Catuneanu et al. (2009). FA 4 occurs only in the uppermost parasequence, and is interpreted to reflect a maximum regression. The middle Curtis (Zuchuat et al. 2018) consists of subtidal to intertidal, well-sorted, amalgamated cross-stratified sandstones (FA 5; Fig. 3G). The base of the middle Curtis is defined by the major transgressive surface (MTS; Fig. 4), which can be traced throughout and beyond the study area, as it also corresponds to the base of Moab Member (Curtis Formation) as well as the Todilto Member (Wanakah Formation) in the Four Corners area (Fig. 2C; Zuchuat et al. 2018). The upper Curtis subtidal to intertidal deposits (FA 6; Fig. $3 \mathrm{H}$ ) conformably overlie the middle Curtis. The eolian dunes in the
Moab Member (FA 7; Fig. 3I) are the lateral (eastern) equivalent of FA 6 (Table 1, Fig. 2C). The Summerville Formation supratidal sabkha deposits (FA 8; Fig. 3J) gradually succeed the Curtis Formation (Table 1). The middle and upper Curtis, the Moab Member, and the Summerville Formation are all contemporaneous units (Zuchuat et al. 2019).

\section{CHARACTERIZATION OF THE J-3 UNCONFORMITY}

The J-3 Unconformity expression is categorized according to geometry and the processes involved in its development (Figs 5, 6, 7). Classifications include: (i) angular unconformity, (ii) paraconformity, (iii) steep incisions, (iv) undulating relief, (v) irregular relief, including fault-plane- and erosion-related relief irregularities, (vi) circular collapsed structures, (vii) hydroplastic sagging, and (viii) sedimentary loading. Categories i to v are erosion-related relief types, whereas categories vi to viii display a deformed unconformity relief. J-3 Unconformity relief and processes are further classified as either facies-dependent, or facies-independent. A relief expression is termed facies-dependent when restricted to a specific facies type, whereas facies-independent relief is not associated with any specific lithology. Faults and fault planes are referred to as pre-, syn-, and post-Curtis features, indicating their development relative to the deposition of the Curtis Formation.

\section{Erosion-Related Relief Angular Unconformity}

Description.-This type of relationship between the Entrada Sandstone and the Curtis Formation is a flat surface (Fig. 7A, B, C), which corresponds either to an angular unconformity (Figs. 2, 7A), or a paraconformity (Fig. 7B, C). In the case of the flat angular unconformity, the J-3 bounds the earthy facies of the Entrada Sandstone (FA 1b) from the lower or middle Curtis (FA 5; Fig. 7A). A similar planar angular unconformity between the two formations is seen in other localities (Notom Ranch area; Fig. 2), where the J-3 Unconformity separates the Entrada Sandstone's Slick Rock Member (FA 1a) from a thin middle Curtis (FA 5).

Interpretation.-Most of these angular unconformities are related to the development of the major transgressive surface (MTS) proposed by Zuchuat et al. (2018) at the base of the middle Curtis, which strongly eroded its substratum (Shadscale Mesa, Figs. 2, 7H-J). These angular unconformities are therefore interpreted to represent a tidal ravinement surface.

\section{Paraconformity}

Description.-This is the most widespread expression of the bounding surface, covering ca. $53 \%$ of the study area (Fig. 6). It is faciesindependent, since it bounds the earthy facies of the Entrada sandstone (FA 1b) and the lower Curtis (Last Chance Desert; Figs. 2, 7B), or the earthy facies and the middle Curtis (NW of Caineville Airstrip, Figs. 2, 7C). The paraconformity separates the Slick Rock Member of the Entrada Sandstone from a thin middle Curtis, just below the Moab Member, in the eastern study area, where the earthy facies is absent (Fig. 2; see also Figs. 3 and 10a in Zuchuat et al. 2018). Note that in northern New Mexico (Fig. 2) the contact between the Slick Rock Member and the Todilto Member can be locally undulating, as a result of "antecedent dune topography" (Kocurek et al. 2018).

Interpretation.-The paraconformity is linked to periods of eolian deflation before and during the Curtis transgression (Mountney 2006), which may or may not have further reworked the Entrada Sandstone's substratum (Kocurek et al. 2018). 
TABLE 1.-Facies associations for the Entrada Sandstone, Curtis Formation, and Summerville Formation.

\begin{tabular}{|c|c|c|c|c|}
\hline $\begin{array}{c}\text { Facies } \\
\text { Association } \\
\end{array}$ & Description & Interpretation & $\begin{array}{c}\text { Facies } \\
\text { Included }\end{array}$ & Formation \\
\hline FA 1a & $\begin{array}{l}\text { FA 1a consists of an amalgamation of very fine- to fine-grained, cross- } \\
\text { stratified sandstone and plane-parallel-stratified to undulating very fine- } \\
\text { grained deposits. FA 1a crops out to the east of the study area, in } \\
\text { Zuchuat et al.'s (2018) Sector } 3 \text {. }\end{array}$ & $\begin{array}{l}\text { FA 1a is interpreted as a coastal wet aeolian dune system (Kocurek and } \\
\text { Havholm 1993; Mountney 2012), with episodic (marine) partial } \\
\text { flooding of interdunes deposits and superficial development of soil } \\
\text { horizons and vegetated horizons. }\end{array}$ & $\mathrm{A}, \mathrm{C}, \mathrm{X}$ & $\begin{array}{l}\text { Entrada Sandstone } \\
\text { Slick Rock Mbr. }\end{array}$ \\
\hline FA $1 \mathrm{~b}$ & $\begin{array}{l}\text { FA } 1 \mathrm{~b} \text { is characterized by rusty-red, parallel-laminated to mottled } \\
\text { siltstone and very fine-grained sandstone, with interdigitating trough } \\
\text { cross-stratified sandstone, rippled cross-stratified sandstone, } \\
\text { evaporitic beds, and isolated, meter-scale cross-stratified sandstone, } \\
\text { commonly interbedded between two } 20-50 \text {-cm-thick undulating } \\
\text { sandstone strata. It thickens northwestwards and pinches out } \\
\text { southwards in the vicinity of Notom Ranch (35) and eastward in the } \\
\text { vicinity of Moab. }\end{array}$ & $\begin{array}{l}\text { FA 1b represents coastal wet aeolian interdunes and a lower-coastal- } \\
\text { plain system at the fringe of FA 1a dune field (Kocurek and Havholm } \\
\text { 1993; Mountney 2012), with episodic (marine) partial flooding of } \\
\text { interdune deposits and superficial development of soil horizons and } \\
\text { vegetated horizons. Simple and compound, isolated coastal aeolian } \\
\text { dunes also occur. FAla and FAlb are contemporaneous units (Zuchuat } \\
\text { et al. 2019) }\end{array}$ & $\mathrm{B}, \mathrm{C}, \mathrm{D}, \mathrm{X}$ & $\begin{array}{l}\text { Entrada Sandstone } \\
\text { earthy facies }\end{array}$ \\
\hline FA 2 & $\begin{array}{l}\text { FA } 2 \text { consists of laterally restricted }(200-500 \mathrm{~m}) \text {, ca. } 2 \text {-m-thick fine- } \\
\text { grained sandstones, locally eroding into or loading onto the underlying, } \\
\text { semiconsolidated FA } 1 \mathrm{~b} \text { earthy facies of the Entrada Sandstone. The } \\
\text { lowermost strata are plane-parallel-stratified and planar-cross- } \\
\text { stratified to low-angle-cross-stratified, and overlain by trough cross- } \\
\text { stratified sandstone and/or ripple-laminated sandstone, in which mud } \\
\text { drapes and rip-up clasts commonly occur. }\end{array}$ & $\begin{array}{l}\text { FA } 2 \text { corresponds to a beach to upper-shoreface depositional system, } \\
\text { with associated tidal channels cut-and-fill, and subordinate tidal } \\
\text { influence. }\end{array}$ & $\mathrm{C}, \mathrm{G}, \mathrm{S}, \mathrm{U}$ & $\begin{array}{l}\text { Curtis Fm. } \\
\text { lower Curtis }\end{array}$ \\
\hline $\begin{array}{l}\text { FA } 3 a \text { and } \\
\text { FA } 3 b\end{array}$ & $\begin{array}{l}\text { FA 3a comprises heterolithic mudstone (FA 3a) to fine-grained } \\
\text { sandstone (FA 3b), arranged in three upward-coarsening packages, } \\
\text { from laminated mudstone to flaser-bedded, scarcely bioturbated } \\
\text { sandstone. It is characterized by abundant bidirectional current } \\
\text { indicators (herringbone cross-stratification) and double mud drapes. } \\
\text { The base of FA 3a is commonly gradational, or sharp, but it can } \\
\text { occasionally be erosional. FA3a occurs in the northern, more distal part } \\
\text { of the shallow-marine system, whereas FA } 3 \mathrm{~b} \text { prevails in its more } \\
\text { proximal and southern zones. In the northern part of the study area, FA } \\
3 \text { also comprises cross-stratified, heterolithic, erosional channel- } \\
\text { shaped features, filled by rounded to well-rounded, gravel-size, } \\
\text { extrabasinal clasts in a matrix of fine- to very coarse-grained sand, with } \\
\text { green mud drapes locally observed between the gravelly foresets. } \\
\text { Gravellydunes also occurring within FA3 are characterized by a sharp } \\
\text { but non-erosional base, and display thin-thick-thin cyclical } \\
\text { progradational pattern, with cm-thick mudstone drapes deposited } \\
\text { between the foresets. }\end{array}$ & $\begin{array}{l}\text { FA } 3 \text { corresponds to a mud- to sand-dominated subtidal-flat } \\
\text { environment. The concave up, erosionally based, conglomeratic } \\
\text { bedforms are interpreted as subtidal channels. Each of the three } \\
\text { upward-coarsening packages are capped by flooding surfaces, and are } \\
\text { interpreted as parasequences sensu Catuneanu et al. (2009). The } \\
\text { relative coarsening towards the south and the more proximal part of } \\
\text { the shallow-marine system indicates higher-energy conditions than in } \\
\text { the north, where the subtidal system was quieter and more mud- } \\
\text { dominated. }\end{array}$ & $\mathrm{H}, \mathrm{I}, \mathrm{J}, \mathrm{K}, \mathrm{L}, \mathrm{M}, \mathrm{N}$ & $\begin{array}{l}\text { Curtis Fm. } \\
\text { lower Curtis }\end{array}$ \\
\hline FA 4a & $\begin{array}{l}\text { FA 4a crops out in the southern and more proximal part of the study } \\
\text { area, and is composed of light-pink, very fine- to fine-grained } \\
\text { sandstones extending over tens of kilometers on the eastern margin of } \\
\text { the San Rafael Swell (Fig. } 3 \text {; see also Zuchuat et al. 2018; Zuchuat et } \\
\text { al. 2019). The plane-parallel-bedded to plane-parallel-laminated } \\
\text { strata thicken southwards (from } 4 \text { to } 15 \mathrm{~m} \text { ), and display single and } \\
\text { double mud drapes, along with rare, unidirectional current ripples, and } \\
\text { herringbone cross-stratification. }\end{array}$ & $\begin{array}{l}\text { FA 4a represents a sandy subtidal to supratidal flat, correlative to the } \\
\text { distal tidal channels of FA } 4 \mathrm{~b} \text {. It occurs only in the uppermost } \\
\text { parasequence of the lower Curtis. }\end{array}$ & $\mathrm{S}, \mathrm{U}, \mathrm{X}$ & $\begin{array}{l}\text { Curtis Fm. } \\
\text { lower Curtis }\end{array}$ \\
\hline FA $4 b$ & $\begin{array}{l}\text { FA } 4 \text { b } 1 \text { to } 10-\text { m-thick, multi-story, coarse-grained, cross-stratified } \\
\text { sandstone with rounded to well rounded, gravel-size extrabasinal clasts } \\
\text { is restricted to the northeastern margin of the San Rafael Swell. mud } \\
\text { drapes along foresets, reactivation surfaces, as well as bidirectional } \\
\text { current indicators, such as subordinate-flow ripples climbing on the } \\
\text { reactivation surfaces, and herringbone cross-stratification commonly } \\
\text { occur. }\end{array}$ & $\begin{array}{l}\text { FA } 4 \mathrm{~b} \text { is interpreted as tidal-channel infillsand splays, distal correlative } \\
\text { of FA 4a. It occurs only in the uppermost parasequence of the lower } \\
\text { Curtis. }\end{array}$ & $\begin{array}{l}\mathrm{C}, \mathrm{H}, \mathrm{I}, \mathrm{L}, \mathrm{M}, \mathrm{N}, \\
\mathrm{S}, \mathrm{U}\end{array}$ & $\begin{array}{l}\text { Curtis Fm. } \\
\text { lower Curtis }\end{array}$ \\
\hline
\end{tabular}

\section{Undulating Relief}

Description.-The most enigmatic type of relief characterizing the J-3 Unconformity was recorded only in the northernmost zone of the study area (Stove Gulch, Fig. 2), where the bounding surface between the earthy facies of the Entrada Sandstone and the lower Curtis displays a sinuously undulating geometry (Fig. 7D) with an amplitude of up to $3 \mathrm{~m}$ and a sinusoidal wavelength of $8-10 \mathrm{~m}$. Mud-dominated heterolithic deposits of FA 3a passively onlap the pre-existing relief (Fig. 7D).
Interpretation.-The exact nature of this type of relief remains unknown, but the passive onlap of FA 3a infill demonstrates that the generation of that relief predated and was not related to the deposition of the lower Curtis.

\section{Steep Incision}

Description.--Steep-sided incisions into the Entrada Sandstone, filled with sediments belonging to the Curtis Formation, are seen at several 
TABLE 1.-Continued.

\begin{tabular}{|c|c|c|c|c|}
\hline $\begin{array}{c}\text { Facies } \\
\text { Association } \\
\end{array}$ & Description & Interpretation & $\begin{array}{c}\text { Facies } \\
\text { Included }\end{array}$ & Formation \\
\hline FA 5 & $\begin{array}{l}\text { FA } 5 \text { consists of a diagnostic lightgreen to white, very fine- to fine- } \\
\text { grained, well-sorted sandstone, which disconformably overlies the } \\
\text { lower Curtis. It features lenticular- to wavy- to flaser-bedded } \\
\text { sandstones, with occasional laminated mudstones, as well as } \\
\text { climbing ripples, and intervals dominated by bidirectional } \\
\text { herringbone cross-stratification. Trough cross-stratified packages } \\
\text { commonly occur in FA 5, with frequent reactivation surfaces and } \\
\text { counter-ripples. The cross-stratified and wavy- to flaser-bedded } \\
\text { sandstone strata are locally arranged in centimeter-scale to meter- } \\
\text { scale tidal bundles with varying amounts of organic and/or } \\
\text { argillaceous matter, deposited as single or double mud drapes. FA } 5 \\
\text { also comprises plane-parallel-stratified, and low-angle cross- } \\
\text { stratified intervals. These facies laterally interfinger with one } \\
\text { another over distances of } 5 \text { to } 40 \text { m. Individual bedforms reach a } \\
\text { maximum height of } 2 \text { to } 4 \mathrm{~m} \text {, and the average bedform size is one to } \\
\text { two orders of magnitude higher than in the underlying lower Curtis } \\
\text { deposits. The base of FA } 5 \text { is sharp or erosional, and can be traced } \\
\text { to throughout the study area, all the way to Ghost Ranch, northern } \\
\text { New Mexico, where it marks the base of the Todilto Member of the Wa- } \\
\text { nakah Formation (Fig. } 2 \text {; Zuchuat et al. } 2018 \text {; Zuchuat et al. } \\
2019 \text { ). The thickness of FA } 5 \text { varies from } 45 \mathrm{~m} \text { at its thickest point, } \\
\text { to ca. } 1 \mathrm{~m} \text { as it thins southwards and westwards. }\end{array}$ & $\begin{array}{l}\text { FA } 5 \text { corresponds to the informal middle Curtis, and is interpreted as an } \\
\text { intricate amalgamation of high-energy, subtidal to intertidal sand- } \\
\text { dominated environments, encompassing tidal flats, tidal channels, tidal } \\
\text { dunes, and tidal bars. Its base is the major transgressive surface (MTS). } \\
\text { FA } 5 \text { reflects an overall higher energy level than the underlying lower } \\
\text { Curtis strata, evidenced by coarser-grained and better-sorted } \\
\text { sediments. The amalgamated bedforms and bedform sets inhibits the } \\
\text { recognition of any traceable stratigraphic surfaces, such as flooding } \\
\text { surfaces or regressive surfaces of marine erosion, accentuating the } \\
\text { contrast with the underlying lower Curtis shallow-marine system. }\end{array}$ & $\begin{array}{l}\mathrm{C}, \mathrm{G},(\mathrm{K}, \mathrm{L}, \mathrm{M},) \\
\mathrm{N}, \mathrm{O}, \mathrm{P}, \mathrm{Q}, \mathrm{R}, \mathrm{S} \\
(\mathrm{X})\end{array}$ & $\begin{array}{l}\text { Curtis Fm. } \\
\text { middle Curtis }\end{array}$ \\
\hline FA 6 & $\begin{array}{l}\text { FA } 6 \text { deposits, consisting of green, siltstone to fine-grained, laterally } \\
\text { extensive, isopachous sandstone beds, distinguished by plane-parallel } \\
\text { stratification, unidirectional current-ripple and herringbone cross- } \\
\text { stratification, conformably overlie the middle Curtis FA } 5 \text { deposits. } \\
\text { Double and single mud drapes also occur in FA 6, together with mud } \\
\text { cracks and thin paleosol horizons. Individual bed-set thicknesses range } \\
\text { from } 3 \text { to } 40 \mathrm{~cm} \text {, and beds thin up-section. Contrasting to the } \\
\text { underlying sediments of FA5, FA6 thins northwards, from a maximum } \\
\text { thickness of approximately } 28 \mathrm{~m} \text { near Hanksville (34) to a minimum of } \\
5 \mathrm{~m} \text { at Sulphur Canyon (1). }\end{array}$ & $\begin{array}{l}\text { FA } 6 \text { constitutes the upper Curtis, and predominantly represents an } \\
\text { upper-subtidal to intertidal sandflat environment, cut by common tidal } \\
\text { channels. FA } 6 \text { also underwent intermittent prolonged subaerial } \\
\text { exposure. FA } 6 \text { reflects an overall lower energy level than the } \\
\text { underlying FA } 5 \text {. }\end{array}$ & $\begin{array}{l}\mathrm{K}, \mathrm{L}, \mathrm{M}, \mathrm{N}, \mathrm{Q}, \mathrm{S}, \\
\mathrm{U}, \mathrm{X}\end{array}$ & $\begin{array}{l}\text { Curtis Fm. } \\
\text { upper Curtis }\end{array}$ \\
\hline FA 7 & $\begin{array}{l}\text { FA7 consists mainly of fine-grained, trough cross-stratified sandstone, } \\
\text { reaching a maximum thickness of ca. } 15-20 \mathrm{~m} \text {, arranged in five } \\
\text { packages. Each package is capped by a traceable erosional surface, } \\
\text { under which abundant rhizoliths can be observed (Zuchuat et al. 2018). } \\
\text { these erosional surfaces are overlain by green, silty very fine to fine- } \\
\text { grained sandstone, displaying ripple or herringbone cross-stratification, } \\
\text { with single and double mud drapes, and arranged in flaser-bedded } \\
\text { packages. Undulating millimeter-scale to centimeter-scale, } \\
\text { structureless sandstone strata also occur on top of these erosive } \\
\text { surfaces. FA7 reaches a maximum thickness of ca. } 50 \mathrm{~m} \text { close to the } \\
\text { Utah-Colorado border, and pinches out northwest of Moab, between } \\
\text { Horse Flies Gulch (20) and Duma Point (19). }\end{array}$ & $\begin{array}{l}\text { FA7 is a coastal dry aeolian dune field (Mountney 2012), arranged in } \\
\text { five sequences separated by supersurfaces, upon which transgressive } \\
\text { water-carried sediments and/or paleosol can be observed. It } \\
\text { corresponds to Doelling's (2001) Moab Member of the Curtis } \\
\text { Formation. FA7 is the lateral and contemporaneous equivalent of FA6 } \\
\text { deposits (Zuchuat et al. 2019). }\end{array}$ & $\begin{array}{l}\mathrm{A}, \mathrm{N}, \mathrm{Q}, \mathrm{S}, \mathrm{T}, \mathrm{U}, \\
\mathrm{X}\end{array}$ & $\begin{array}{l}\text { Curtis Fm. } \\
\text { Moab Mbr. }\end{array}$ \\
\hline FA 8 & $\begin{array}{l}\text { FA } 8 \text { is characterized by rusty red to dark brown, evaporite-rich } \\
\text { mudstones and siltstone deposits, which also contains centimeter-thick } \\
\text { to decimeter-thick, light gray, ripple cross-stratified sandstone beds. FA } \\
8 \text { strata sharply overlie the eolian dunes of FA7, whereas the contact } \\
\text { between FA } 8 \text { and the underlying strata of FA } 6 \text { sub- to supratidal } \\
\text { sediments is gradational. }\end{array}$ & $\begin{array}{l}\text { FA } 8 \text { sediments were deposited in a supratidal, lower-coastal-plain } \\
\text { environment, with episodic marine flooding, while the Curtis sea } \\
\text { regressed. }\end{array}$ & $\mathrm{U}, \mathrm{V}, \mathrm{W}, \mathrm{X}$ & Summerville Fm. \\
\hline
\end{tabular}

locations (Sven's Gulch, Uneva Mine Canyon, eastern cliffs of Cedar Mountain, and Notom Ranch; Fig. 2). Incisions range between 10 and 70 $m$ in width (Notom Ranch and Uneva Mine Canyon, respectively), and reach depths between 3 and $15 \mathrm{~m}$. At Sven's Gulch, the incision is ca. $45 \mathrm{~m}$ wide, and carved ca. $10 \mathrm{~m}$ into the underlying earthy facies of the Entrada Sandstone (FA 1b, Fig. 7E). These narrow and localized features are classified as facies-dependent, due to all observed incisions forming solely in the earthy facies of the Entrada Sandstone. At Sven's Gulch (Fig. 2), the incision eroded not only the Entrada Sandstone but also the Curtis FA 2 shoreface and FA 3a subtidal deposits (Fig. 7E). Locally, boulders of Entrada material are contained within the incision infill (Fig. 7E).
Interpretation.-The incisional surfaces are interpreted to be the product of channelized tidal currents, acting on a nonconsolidated to semiconsolidated Entrada and Curtis substratum. The cannibalization of younger FA 2 and FA 3a deposits, as well as the presence of Entrada material in the channel infill, imply that this incisional feature was not present before, but rather was formed by a short-lived regressive episode, which funneled tidal forces and carved into poorly lithified substratum, while encapsulating eroded material into the resultant infill. Notably, the Sven's Gulch incision belongs to the second parasequence observed in the lower Curtis, and shows entire cannibalization of its substratum (Zuchuat et al. 2018), whereas the overlying subtidal channel deposits (FA 4b) belong to the third parasequence of the lower Curtis (Fig. 4). 


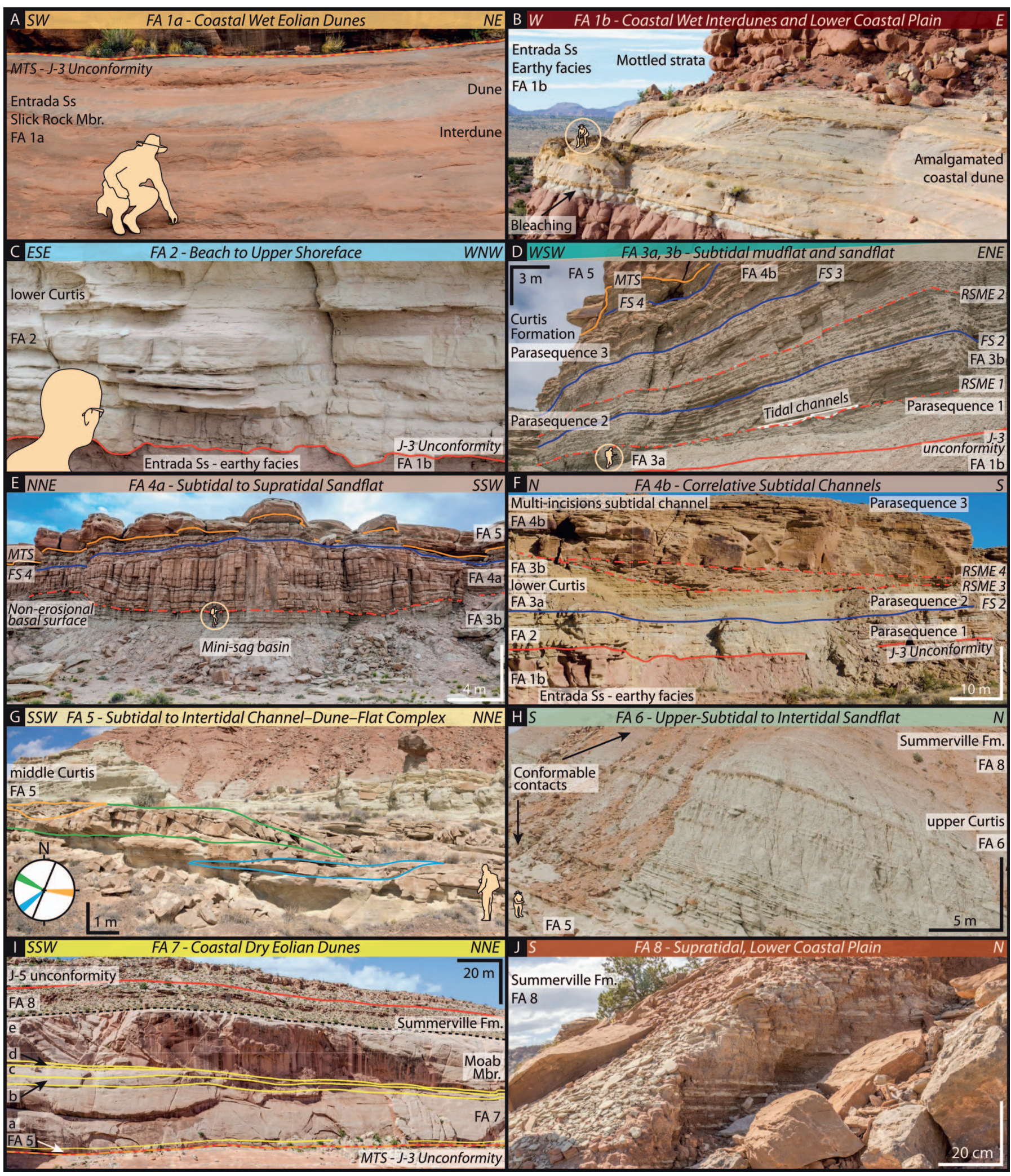

Fig. 3.- Summary panel of the Facies Associations (FA) cropping out in the study area. A) Example of wet coastal eolian dunes of FA 1a (Entrada Sandstone, Slick Rock Member). B) Amalgamated eolian coastal dunes in the fine-grained, marginal marine earthy facies of FA $1 \mathrm{~b}$ (Entrada Sandstone). Note the bleached horizon directly below the dunes. Geologist for scale. C) High-energy upper-shoreface to beach deposits, with rip-up clasts and occasional mud drapes. Note the loaded and eroded irregular geometry of the J-3 Unconformity. D) Typical stacking architecture of subtidal mud-dominated (FA 3a) and sand-dominated (FA 3b) heterolithic flat deposits. E) Mini sag basin generated by the collapse of FA $3 \mathrm{~b}$ deposits, as FA 4a sand-rich subtidal to supratidal sandflat was being deposited. F) Two incision phases of FA 4b subtidal channel. G) Bidirectional tidal inlets (green and orange contours) and a third southwestward laterally accreting tidal channel (blue contour) in a surrounding subtidal- to intertidal-flat environment (FA 5). 


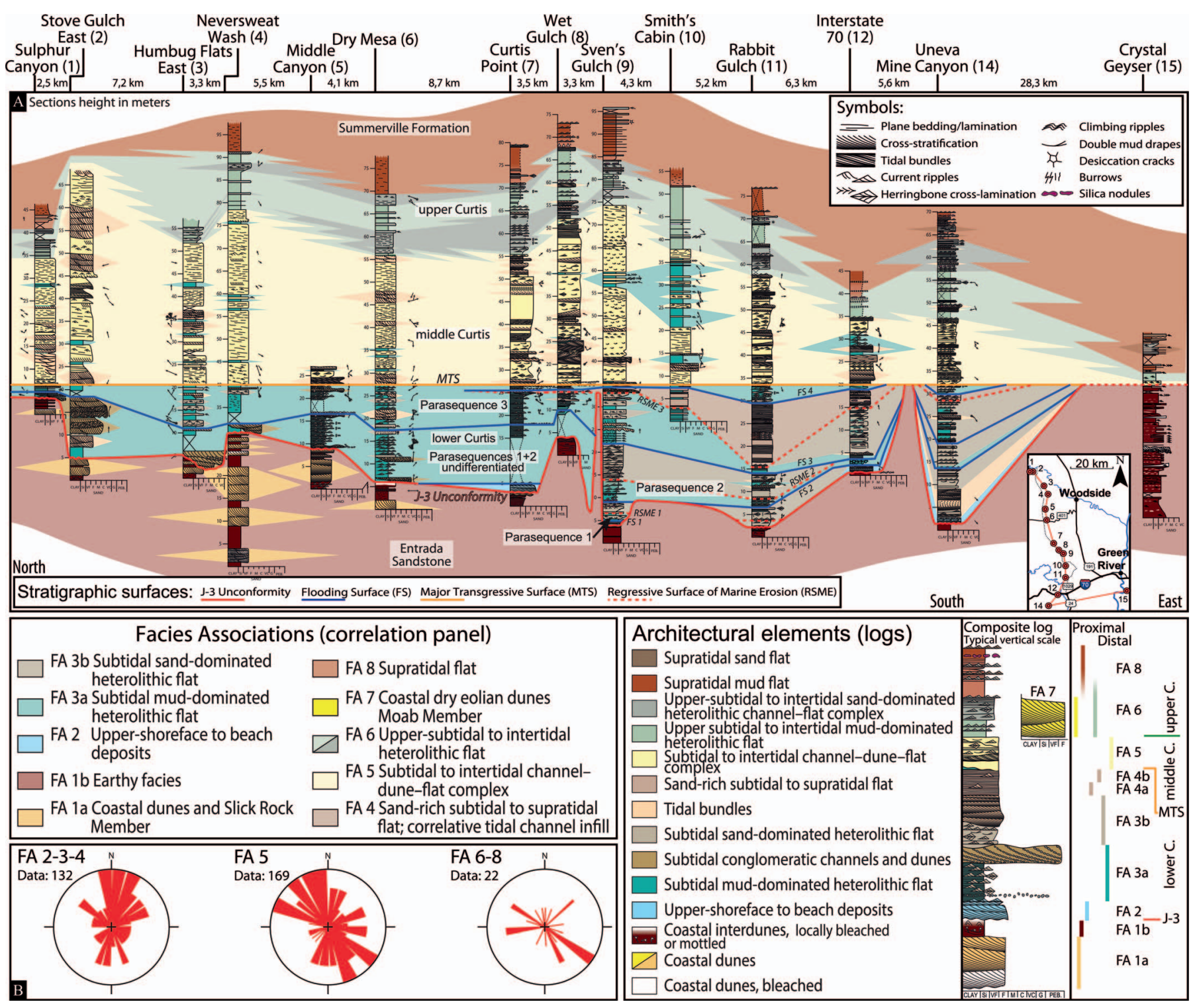

FIG. 4.-A) N-S-E oriented correlation panel along the NW margin of the San Rafael Swell, and the correlative spatial distribution of facies associations across the Curtis basin. The datum corresponds to the major transgressive surface (MTS). B) Rose diagrams displaying the paleocurrent measurements for the lower Curtis (FA 2, FA 3, and FA 4), the middle Curtis (FA 5), and the upper Curtis-Summerville Formation intervals (FA 6 and FA 8). Modified from Zuchuat et al. (2019).

\section{Irregular Relief}

Description.-The J-3 Unconformity irregular relief, or disconformity, is the second most widespread bounding-surface expression across the study area, covering ca. $43 \%$ of its surface. Its wavelength ranges from 0.5 to $200 \mathrm{~m}$, and its amplitude varies from 0.1 to $23 \mathrm{~m}$, which corresponds to the highest relief value measured throughout the study area (Cedar Mountain, Fig. 7K). This type of irregular relief is partially facies-dependent, as it separates the earthy facies of the Entrada Sandstone (FA 1b) from either (i) lower Curtis deposits (Cedar Mountain, or Humbug Flat East, Fig. 2), where tidally reworked, cross-stratified, basal flash-flood conglomerates rest disconformably on strata of the earthy facies (Fig. 7G); or (ii) the middle Curtis channel, dune, and flat complex (FA 5), which eroded into its substratum during the major transgression (Fig. 7J).

Interpretation.-Such irregular relief is therefore related to both (i) sporadic flash floods gently incising into the Entrada Sandstone before or during the Curtis sea transgression, and (ii) syn-transgression tidal ravinement (Zuchuat et al. 2018). 


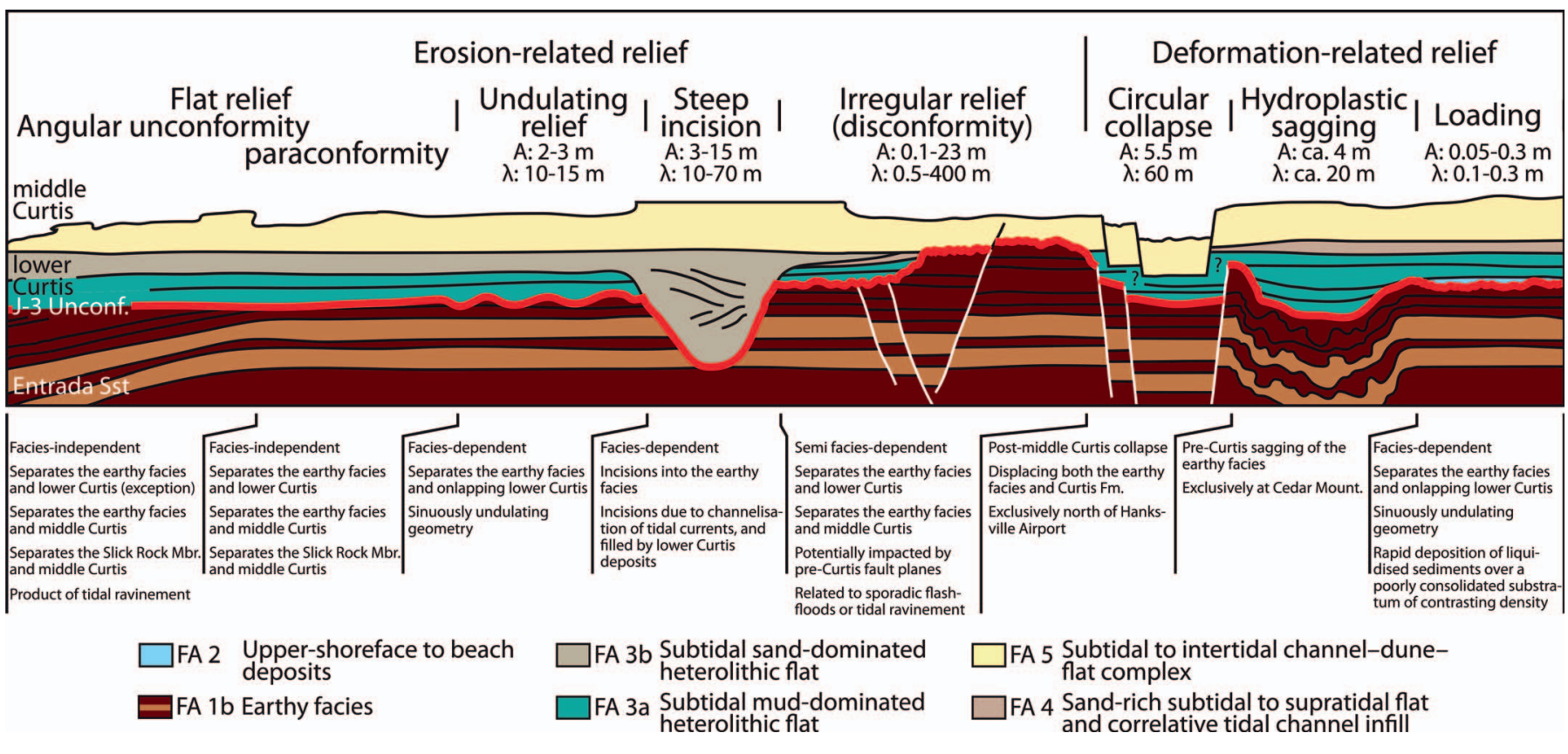

FIG. 5.- Conceptual diagram illustrating the five erosion-related and the three deformation-related types of relief documented throughout the study area. The vertical and horizontal scales are not representative of the reality. A, amplitude; $\lambda$, wavelength.

\section{Impact of Pre-Existing Faults on the Relief}

The impact of pre-Curtis faults on the J-3 relief can be regarded as: (i) non-existent, as faults were eroded subsequently, yet the fault system did generate small (half-)graben structures (Humbug Flats East, Figs. 2, 7F); or (ii) limited, and marked by partial step-like subsequent reworking (Shadscale Mesa, Figs. 2, 7H, I). These faults are either planar (Shadscale Mesa, Fig. 7H, I), slightly curved, or related to circular collapsed calderalike structures in the earthy facies of the Entrada Sandstone (Hanksville Airport, Figs. 2, 7L, M). All pre-Curtis faults displaced the earthy facies of the Entrada Sandstone, whereas post-Curtis faults also cut through the underlying Slick Rock Member. Although the exact timing of faulting episodes, as well as their triggering mechanism(s) remain unknown, it is likely that most of them resulted from local structural disturbances, rather than being associated with regional deep-rooted tectonic activity.

At Shadscale Mesa (Fig. 2), the outcrop can be separated into three zones, each characterized by a different fault-related J-3 Unconformity expression (Fig. 7H). In the northern section of the outcrop, the NEdipping normal faults displacing earthy facies (FA 1b) have no impact on the unconformity geometry, as their fault planes were entirely removed by subsequent erosion (Fig. $7 \mathrm{H}$ ). It is suggested that the relief generated by these fault planes was mainly smoothed by a pre-Curtis and nonmarine process, such as eolian deflation, as the weak mechanical strength of saturated, marginal marine loess deposits tend to work against the longlasting and unaltered, subaerially exposed fault planes (Yang et al. 2016).

Towards the central part of the outcrop, where the J-3 separates the earthy facies from the overlying middle Curtis, NE-dipping normal faults generated a steplike geometry of ca. 35 to $40 \mathrm{~cm}$ (Fig. 7H, I). Some of these pre-existing fault planes in the Entrada Sandstone did influence the subsequent marine erosion accompanying the middle Curtis major transgression and deposition of FA 5a deposits, by resisting erosion locally resulting in steplike irregular relief (Fig. 7H, I; Zuchuat et al. 2018). Farther south, normal faults dip towards the SW (Fig. 7H). Contrastingly, these pre-existing SW-dipping fault planes had no impact on middle Curtis deposition. However, one south-dipping normal fault shows evidence of reactivation, as the throw reaches ca. $2 \mathrm{~m}$ in the earthy facies of the Entrada
Sandstone, while in the overlying middle Curtis displays a throw of only ca. $60 \mathrm{~cm}$ (Fig. 7H, I). One laterally continuous paleosol horizon exposed throughout a faulted cliff face demonstrates that at least $3.2 \mathrm{~m}$ of earthy material was eroded by eolian deflation before the Curtis sea transgressed the region (Fig. $7 \mathrm{H}, \mathrm{I}, \mathrm{J}$ ).

In the northern section of the outcrop, the unconformity was partially modified subsequently by strong currents accompanying deposition of the lowermost FA 2 deposits of the lower Curtis. As the transgression progressed, and deposited FA 3 subtidal sediments, the erosive power of the currents diminished, as evidenced by a thicker remaining earthy facies of the Entrada Sandstone (Fig. 7H). Eventually, the tidal currents accompanying the major transgression at the base of the middle Curtis further modified the unconformity, before the SW-dipping normal fault to the south of the outcrop (Fig. 7J) was reactivated, giving the J-3 Unconformity its final composite expression.

The fact that pre-existing faults dipping towards the NE influenced the Major Transgression and deposition of the middle Curtis in the central part of the outcrop, whereas the northern part of the cliff was not impacted by their occurrence, suggests that a differential hardening of these fault planes occurred, with the latest to be flooding becoming the most resistant.

\section{Deformation-Related Relief Circular Collapse}

Description.- In the SW of the study area (North of Hanksville Airport, Figs. 2, 7L, M), the J-3 Unconformity was strongly impacted by post-Curtis ring faulting (Marti et al. 1994; Gudmundsson 2007). As the original unconformity was sculpted by eolian deflation and localized, mscale, water-induced incision, earthy facies of the Entrada Sandstone (FA 1b) were deformed by sand-mobility-related gentle contractional folding, followed by a passive infill of the available accommodation by lower Curtis deposits (FA 3, Fig. 7L). After the major Curtis sea transgression led to deposition of the middle Curtis (FA 5), a sudden $5.5 \mathrm{~m}$ circular collapse occurred, forming a 60-m-wide, steeply dipping ring-fault system, which displaced both formations (Fig. 7L, M). The maximum throw per individual fault reaches ca. $2.65 \mathrm{~m}$. The ring-shaped surface expression 


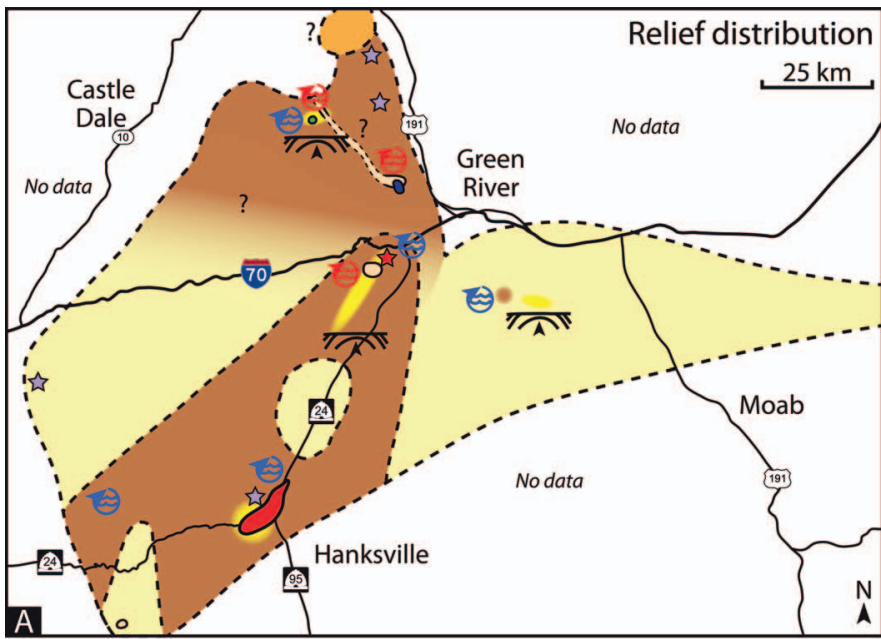

\begin{tabular}{|c|c|}
\hline Processes & Pre-Curtis Fm. ', lower Curtis ímiddle Curtis \\
\hline Eolian deflation & $\begin{array}{l}\text { Active over unflooded } \\
\text { areas }\end{array}$ \\
\hline $\begin{array}{l}\text { Water-induced erosion: } \\
\text { - Flash-floods } \\
\text { - Tidal ravinement } \\
\text { - Tidal funnelling } \\
\text { and incision }\end{array}$ & wm um Potentially active over unflooded areas \\
\hline Structural folding - uplift & 5 \\
\hline Brittle faulting & - \\
\hline Circular collapse & 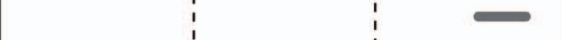 \\
\hline Hydroplastic sagging & $a^{\prime}$ \\
\hline \multirow[t]{3}{*}{ Loading } & b \\
\hline & $t 1$ \\
\hline & $\begin{array}{l}\text { t2 Major transgression (MTS) } \\
\text { t1 Onset of the Curtis Sea Transgressive ST }\end{array}$ \\
\hline
\end{tabular}

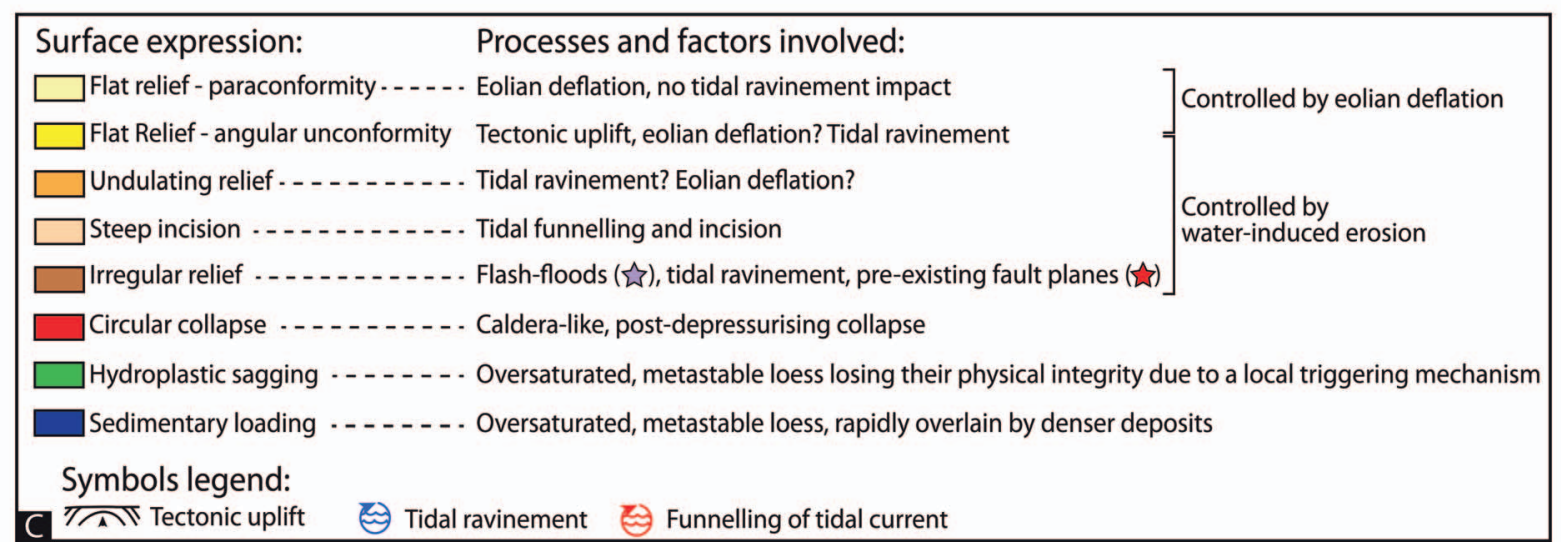

FIG. 6.-A) Map displaying how the various types of relief are distributed throughout the study area. B) Diagram showing the relative timing of all the identified processes involved in the shaping of the unconformity. Three time periods are identified here: the Pre-Curtis Formation period corresponds to the period predating the start of the Curtis sea transgression over the study area (t1), the second period corresponds to the time during which the lower Curtis was being deposited, and the third period corresponds to the processes involved in the shaping of the unconformity postdating the major transgression, and accompanying the deposition of the middle Curtis (t2). C) Legend linking the different types of relief to the various processes involved in the making of the J-3 Unconformity.

of these faults, as well as other similar circular collapsed structures, are observable from satellite and aerial images of the area (Fig. 7M). The capping Summerville Formation, where present, does not show any evidence of similar deformation. Notably these collapsed structures are more resistant to weathering than the unaltered, encasing deposits, leaving behind tubular and pillar-like structures.

Interpretation.-These circular collapse features are thought to be formed by depressurization similar to the process(es) forming calderas (Marti et al. 1994; Gudmundsson 2007).

\section{Hydroplastic Sagging}

Description.-The only recorded example of hydroplastic sagging is in the NW of the study area (Cedar Mountain's cliff side, Fig. 2), generating a 4m-deep and 20-m-wide trough in the uppermost earthy facies of the Entrada Sandstone (FA 1b, Fig. 7N). The infilling marine deposits (FA 3a) onlap the trough and consist of siltstone and very fine-grained sandstone strata.

Interpretation.-The onlapping nature of the marine infill indicates that the Entrada Sandstone beds sagged before the deposition of the lower Curtis. Notably, the Entrada Sandstone strata partially retained primary bedding, both on the mini-sag margins, and across the deformed zone, in that individual hydroplastically deformed strata can be correlated across. The triggering mechanism for such hydroplastic mini-sag basins remains disputed.

\section{Loading}

Description.-The J-3 Unconformity was also directly impacted by softsediment deformation and sedimentary loading of Curtis Formation beach to upper-shoreface deposits (FA 2) into the underlying earthy facies of the Entrada Sandstone (Fig. 7O). This is visible in one particular location (Sven's Gulch, Fig. 2), where cut-and-fill structures are also recognized. Accordingly the J-3 Unconformity is irregular, with dm-scale relief.

Interpretation.-These deformation and loading structures require rapid deposition of liquefied sediments onto a poorly consolidated substratum of contrasting density (e.g., Owen 2003; Oliveira et al. 2011).

\section{DISCUSSION}

\section{Spatio-Temporal Complexity of the J-3 Unconformity}

The spatial distribution of the J-3 Unconformity relief does not reflect any predictable pattern (Fig. 6A, B). Nevertheless, the northern part of the study area generally displays a greater vertical relief, with a maximum of 
$23 \mathrm{~m}$ (Cedar Mountain, Fig. 7K) which diminishes southward. In the east of the study area, where the Slick Rock Member (Entrada Sandstone) is directly overlain by the Curtis Formation, the J-3 Unconformity is mostly an eolian deflated paraconformity (sensu Mountney 2012). However, when the unconformity occurs above the earthy facies, it is characterized by more variable relief, both in terms of geometry and formation processes, as evidenced by the presence of steep tidal incisions, undulating relief, irregular relief by tidal ravinement, sedimentary loading, hydroplastic sagging, and circular collapse, together with flat angular unconformities and paraconformities.

The fact that some of the deformation-related features in the J-3 Unconformity are recorded only at one specific locality makes it difficult to explain the development of the unconformity by one single and exclusive factor. Since the earthy facies are laterally extensive and internally homogeneous, any change in structural strength, for instance due to oscillating water saturation conditions (Assallay et al. 1997; Li et al. 2016), or any regional triggering mechanism, such as earthquakes linked to large tectonic structures, would be expected to impact those sediments similarly at more than one location spatially and temporally, rather than generating location-specific deformation types. Thus, a more spatially restricted process responsible for this localized structural deformation is required, whose triggering factor(s) remain yet to be identified.

These deformation-related features occurred both at different locations but also different depths relative to one another. The infill of the hydroplastic mini-sag (Fig. 7N) passively infilled the negative relief, which implies that the sagging geometry represented a paleo-ground, doline-like trough. The loading structures (Fig. 7O) developed at near-surface depth, once the lowermost Curtis Formation strata were deposited. The ring-fault collapsed system (Fig. 7L) was generated at greater depth than the hydroplastic mini-sag and loading structures, as the overlying Curtis Formation is distorted. However, since the capping Summerville Formation shows no evidence of deformation, these ring-fault collapsed structures must have developed at depth equaling the Curtis Formation thickness and age. Despite these differences, each of these three geometric expressions of deformation-related unconformity relief requires a nonconsolidated to poorly consolidated underlying earthy facies in order to develop.

\section{Relative Timing of Events}

Any regional correlation of events is limited by the lack of absolute dating, the absence of a regional marker bed in the Entrada Sandstone, and the heterolithic nature of the Curtis Formation (Zuchuat et al. 2018).
Therefore, only a relative timing of different processes and events can be established (Figs. 6C, 8). This timing shows that the different erosional and deformational processes involved in shaping the J-3 Unconformity overlapped in both time and space, highlighting the composite nature of the surface. Figure $6 \mathrm{C}$ and Figure 8 illustrate the relative timing relationship between each of these processes affecting the J-3 Unconformity: (i) before the lower transgression of the Curtis sea, (ii) after the lower transgression of the Curtis sea (t1, Figs. 6, 8), accompanied by lower Curtis deposition, and (ii) after the Major Transgression (t2, Figs. 6, 8) (Zuchuat et al. 2018), marking the onset of the middle Curtis deposition.

An example of processes varying spatially includes eolian deflationshaping of the unflooded J-3 Unconformity on a regional to sub-regional scale (Fig. 8A, D, F, K, Q, R), whilst flash floods reworked the J-3 locally (Fig. 8L). Moreover, simultaneous tidal ravinement (Fig. 8G) and loading (Fig. 8B) may have impacting the J-3 Unconformity where the Curtis sea had already flooded the Entrada Sandstone. As such, tidal reworking of the J-3 surface was a time-dependent process, in that its impact varied depending on whether the system was undergoing a transgression or a regression. Localized, steep, and narrow incisions occurred during shortlived regressive phases as currents were funneled (Fig. 8C), contrasting with the widespread irregular relief generated by transgressive tidal ravinement (Fig. 8H). Although short-lived regressions cutting into the underlying and semiconsolidated earthy facies of the Entrada Sandstone had only a limited impact, subsequent relative base-level falls caused significant reworking in the Curtis Formation (Sven's Gulch, Fig. 7E). Here, subtidal channels (FA $4 \mathrm{~b}$ ) eroded more than $5 \mathrm{~m}$ into the underlying FA 3a and FA 3b deposits of the lower Curtis (see Fig. 4C, D, E in Zuchuat et al. 2018). Consequently, the J-3 Unconformity exposes the intricate imprint that cyclical relative sea-level or base-level changes have on the development of such bounding surfaces. This was similarly demonstrated by Rameil et al. (2012), who showed how short-lived transgressiveregressive cycles impacted the development of "discontinuity surfaces" on a Cretaceous carbonate platform.

Contrasting with the potential synchroneity of eolian deflation and tidal ravinement, hydroplastic sagging and sedimentary loading correspond to a relatively fixed point in time, pre-transgression and post-transgression, respectively. However, it is impossible to exclude the possibility of hydroplastic sagging developing in a post-transgression context. Moreover, similarities exist between the underlying tidally influenced beach to uppershoreface deposits (FA 2) and the overlying subtidal complex of channels, dunes, and tidal flats (FA 5), notably in terms of grain size and rapid settling time. However, the spatio-temporal limitation of sedimentary

FIG. 7.-Overview of the different types of relief, as they appear in the field. A) Example of an angular unconformity between the earthy facies of the Entrada Sandstone and the middle Curtis (barely visible on the photo, less than a meter thick), conformably overlain by the upper Curtis, which then grades into the Summerville Formation. B) Paraconformable contact between the earthy facies of the Entrada Sandstone and the lower Curtis. C) Paraconformable contact between the earthy facies of the Entrada Sandstone and the middle Curtis. Note that the J-3 Unconformity has merged with the major transgressive surface, defining the base of the middle Curtis (Zuchuat et al. 2018). Geologist for scale. D) Enigmatic occurrence of an undulating relief, observed only in the northern part of the study area, at Stove Gulch, separating the earthy facies of the Entrada Sandstone from the lower Curtis. E) Example of a steep tidal incision at Sven's Gulch. The black dashed line contours the base of this incision, which eroded first into its intraformational substratum (FA 2 (black arrow), FA 3a) before cutting into the underlying earthy facies of the Entrada Sandstone. The incision was filled in by FA 3b deposits, in which a boulder of Entrada Sandstone can be observed (brown arrow). Note how the overlying subtidal channel (FA 4b) also truncates its substratum but does not reach the J-3 Unconformity. F) Example of an irregular, erosion-related relief at the base of the lower Curtis, which was not impacted by pre-existing normal faults occurring in the earthy facies of the Entrada Sandstone. G) Close up on this irregular erosional contact, as the lower Curtis deposits carved into their Entrada Sandstone's substratum. Note that the whole succession was subsequently faulted. H, I, J) See text for detailed explanations. Shadscale Mesa outcrop, where the middle Curtis completely truncated its lower Curtis Substratum, before starting to erode into the earthy facies of the Entrada Sandstone. Note that the transgression accompanying the lower Curtis' deposition was not impacted by pre-existing normal-fault planes occurring in the earthy facies of the Entrada Sandstone, whereas the major transgression and the associated middle Curtis were impacted by these pre-existing normal fault-planes, forming 30-50 cm escarpments, which suggests a differential hardening of these fault planes between the deposition of the lower and the middle Curtis. K) Irregular erosional relief of ca. 23 m, visible at Cedar Mountain. The J-3 Unconformity separates the earthy facies of the Entrada Sandstone from the lower Curtis. The stratal arrangement in the lower Curtis might have required some local syndepositional tilting, to account for the thickness variations and the sedimentary architecture of the unit. The three black arrows indicate the lateral-accretion direction of cross-stratified channelized sandstone bodies. L, M) Cross section across, and map view of, one of the circular collapse structure present in the vicinity of Hanksville Airport. Black lines indicate normal faults, and red ones correspond to local thrusts. The dashed lines indicate uncertainties in the interpretation. N) Hydroplastic sagging at the top of the Entrada Sandstone. The depression was passively infilled by the subtidal deposits of the lower Curtis. Note the postdepositional faulting of the entire succession. O) Loading structures occurring at the interface between the lower Curtis beach to upper-shoreface deposits (FA 2) and the underlying earthy facies of the Entrada Sandstone. 


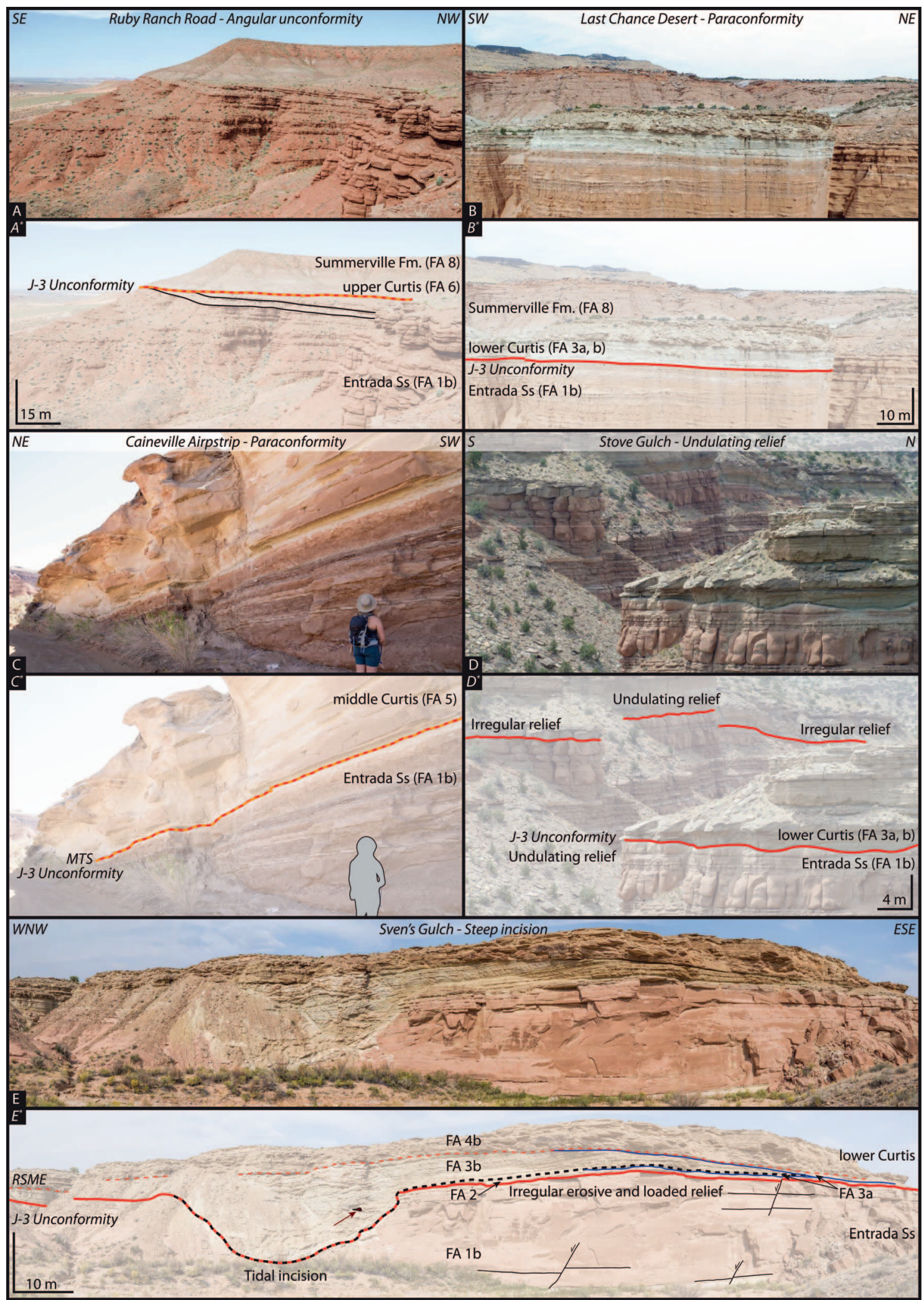




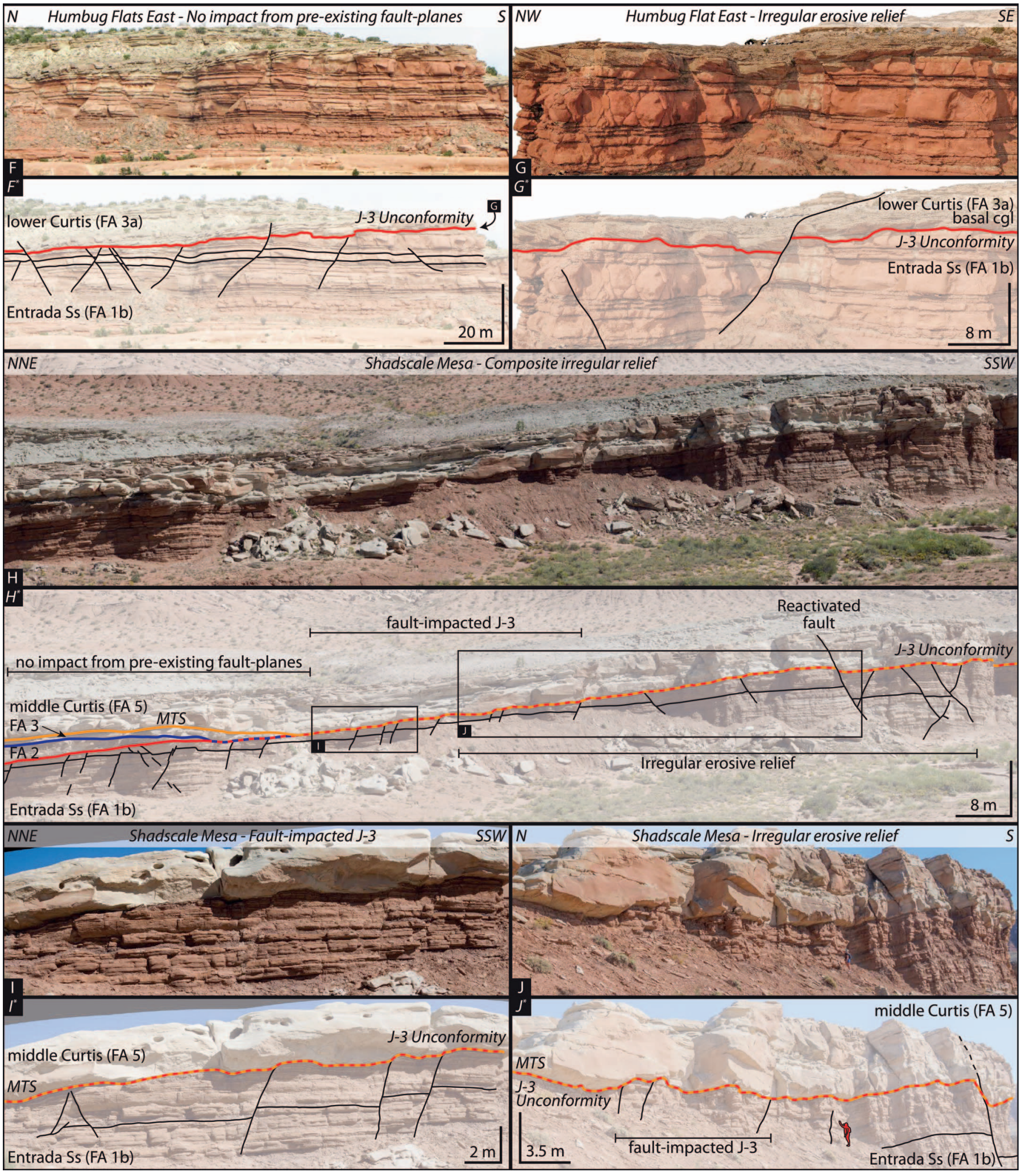

FIG. 7.-Continued. 


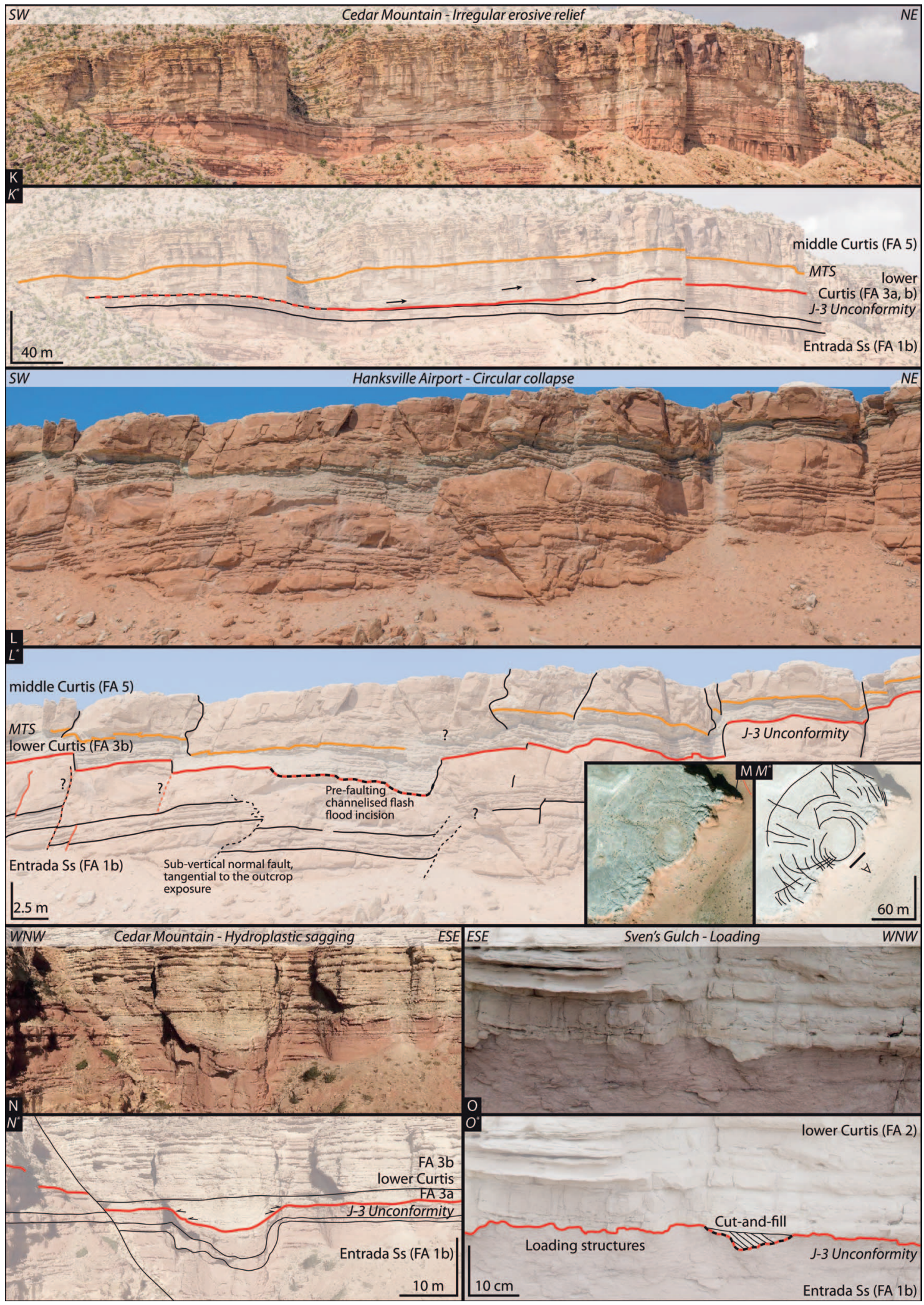

FIG. 7.-Continued. 
loading below FA 2 and the lack thereof at the base of FA 5 imply a relative hardening of the substratum between deposition of the two units.

The flat and extensive paraconformity(ies) capping both the earthy facies and the Slick Rock Member is mostly associated with eolian deflation (Figs. 6, 7B, 8; see also Zuchuat et al. 2018). However, where pre-existing relief existed (Shadscale Mesa, Hanksville Airport; Figs. 2, $8 \mathrm{E}, \mathrm{F})$, eolian deflation was able only to smooth the relief, but never to flatten it entirely. This could be explained by an enhanced cohesion in the exposed sediments due to a high degree of saturation (Mountney 2006, 2012). As eolian deflation could only smooth but not flatten pre-existing relief on its own, and the transgression accompanying the middle Curtis eroded the underlying uplifted lower Curtis at an angle (t2, Fig. 8J; Zuchuat et al. 2018). Thus, it is interpreted that flat angular unconformities separating the Entrada Sandstone from the middle Curtis were most likely created by tidal ravinement forces during the major transgression, whereas eolian deflation likely played a minor role in the development of such a geometry before the transgression.

Nevertheless, the relief generated by the major transgression (Fig. 9), which defines the base of the middle Curtis, is non-unique (sensu Burgess and Prince 2015), as it corresponds to a flat angular unconformity (Fig. 7A; see also Fig. 7 in Wheatley et al. 2016), a paraconformity (Figs. 7B, C, 8; see also Zuchuat et al. 2018), or it displays an irregular erosional geometry (Fig. 7H-J). The latter occurs only where the earthy facies crops out (Fig. $7 \mathrm{H}-\mathrm{J})$, whereas the flat angular unconformity and the paraconformity are facies-independent, as they cap both the earthy facies and the Slick Rock Member (Figs. 7C, 8, 9; see Wheatley et al. 2016 and Zuchuat et al. 2018). It is unclear why the uniform and widespread earthy facies was impacted differently by a transgression which deposited an extensive and relatively homogeneous sandstone (FA 5), this may be due to the intrinsically complex spatial energy distribution within a tide-dominated basin (Kvale 2012; Wang 2012 and references therein). Such a random spatial dispersion of erosive forces, as observed along the J-3 Unconformity, contrasts with the homogeneous grain-size and bedform distribution which characterize the FA 5 deposits. This suggests that the type of unconformity, the type of relief, and the processes accompanying the major transgression might all be facies-independent, and this facies independence is further amplified when the Slick Rock Member is considered (Fig. 9).

In summary, the composite nature of the J-3 Unconformity can be described in terms of processes involved in the shaping of the bounding surface at each individual locality. The complexity increases when considering its spatial and temporal variability, and when attempting correlation of the contact in multiple localities. This is due to the apparent randomness of the spatio-temporal distribution of erosive forces and local deformational mechanisms, and the limited chronostratigraphic and lithostratigraphic correlation constraints. The J-3 Unconformity is therefore not one single unconformity, but the amalgamation of several sub-seismic erosional and deformation surfaces.

\section{Unconformities as Time Barriers and Sequence Boundaries}

The complexity of the J-3 Unconformity raises a few broader questions: (i) is such an intricate bounding surface an actual unconformity, and hence, a genuine time barrier, and (ii) can such a composite surface be considered to be a sequence boundary?

The definition of an unconformity requires the surface to be erosional or nondepositional, separating younger strata above from older deposits below, thus representing a "significant hiatus" (Mitchum et al. 1977). It is consequently regarded as a time barrier. However, when considering depositional systems across entire basins, regional surfaces categorized as unconformities are commonly not the result of one single bypass or erosive event, but the amalgamated end product of multi-episodic erosiontransport-deposition events (Holbrook and Bhattacharya 2012; Blum et al. 2013; Hodgson et al. 2016; Miall 2016; Gani 2017). Due to the variety of processes involved, and the continuity of spatio-temporally unevenly distributed erosion-transport-deposition events, these surfaces are time transgressive or diachronous, as they do not separate the same older deposits below from younger deposits above everywhere in the basin (Holbrook and Bhattacharya 2012; Blum et al. 2013; Hodgson et al. 2016; Gani 2017). This study demonstrates that the J-3 Unconformity is a composite surface impacted by several processes acting at different places at different times. The J-3 Unconformity shows resemblances to other heterochronous and diachronous bounding surfaces, such as the "regional composite scour" of Holbrook and Bhattacharya (2012), which is the product of multiple episodes of incision-transport-deposition in a fluviodeltaic system, or the "diachronous lithological basal surface" of Hodgson et al. (2016), from the study of deep-water systems.

In order to assess the use of Mitchum et al.'s (1977) definition of unconformities in a basinal setting similar to this study, a hypothetical, low-gradient, transitional depositional model is considered (Fig. 10). This hypothetical basin consists of a tidally influenced shallow-marine domain adjacent to an active coeval eolian system. The basin is assumed to have undergone a progressive climate change towards a more humid period, a constant rate of relative sea-level rise, and a steady sediment supply. These two systems coexist in the basin, meaning sediments are deposited, transported and eroded at the same time. As climatic conditions change and relative base level and sea level rise, the sediment budget of the eolian system diminishes, reworking existing strata and forcing bedform size to decrease (Kocurek 1988; Crabaugh and Kocurek 1993; Carr-Crabaugh and Kocurek 1998; Mountney 2012; Mountney 2006; Rodríguez-López et al. 2013). Consequently, the eolian system can be considered as terminated at the outcrop scale, potentially truncated by a deflation and/or ravinement surface, and unconformably overlain by shallow-marine strata. However, as discussed by Gani (2017), when the entire basin is taken into account, a depositional system can migrate, change, and adapt to new conditions concurrently to the other(s) system(s) in the same basin. This may imply that two developing depositional systems, marine and terrestrial (eolian), can coexist during a relative sea-level rise, and be separated by a transgressive and/or a ravinement surface, which is not necessarily a basinwide time barrier (Fig. 10). These conditions are similar to what has been observed on continental shelves by Nummedal and Swift (1987), Martinsen and Helland-Hansen (1995), and Helland-Hansen and Martinsen (1996).

Such a simplistic two-dimensional model does not, however, account for the real three-dimensional and temporal variations of the rate of relative sea-level rise, sediment supply, orbital forcing, and differential regression, among other factors. These may impact the system at different places over different periods, and at different scales (Miall 2016; Gani 2017). If the time-transgressive nature of such bounding surfaces can be shown already on a 2D model, this property will only be enhanced in 3D studies (Martinsen and Helland-Hansen 1995), and 4D studies (Burgess and Prince 2015; Madof et al. 2016; Miall 2016; Gani 2017).

The present study, in conjunction with other works, demonstrates that regional composite bounding surfaces are commonly not unconformities sensu stricto, but often just represent bounding surfaces between contemporaneous and dynamic depositional systems. However, such composite surfaces still encapsulate meaningful information regarding basin development, especially in terms of process identification and interactions. The concept of unconformities as time barriers, as defined by Mitchum et al. (1977), has therefore proven to be limited to local considerations rather than basinwide applications. A renewed definition should emphasize the various processes involved in the making of such a surface, and the environmental changes associated with these, while keeping the time-barrier aspect of it to a minimum.

As of now, unconformities are often associated with relative sea-level falls, and consequently interpreted as sequence boundaries, together with their correlative conformities (Mitchum et al. 1977; Vail et al. 1977; Van 
Composite J-3 Unconformity

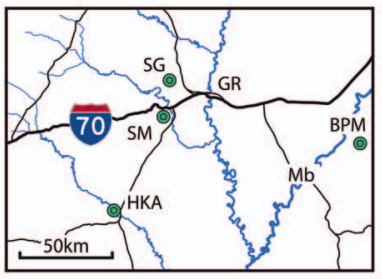

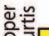

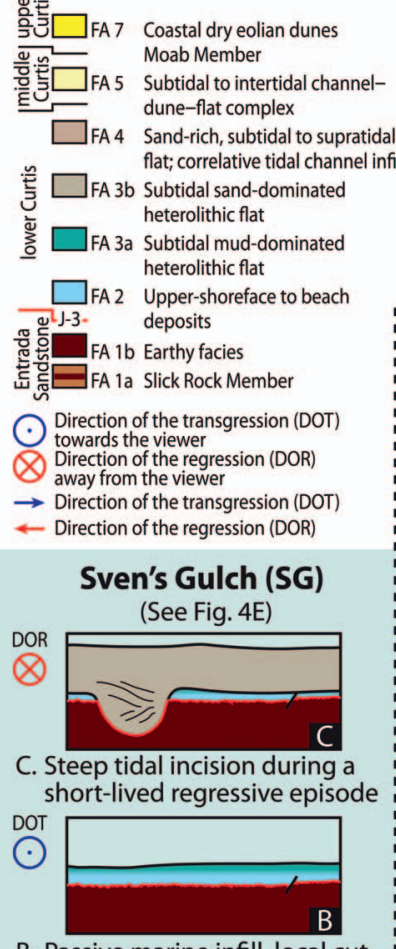

B. Passive marine infill, local cutand-fills, sedimentary loading, and small normal faulting

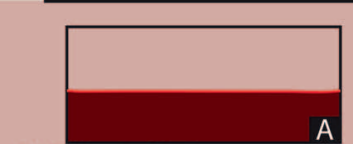

A. Eolian deflation
3 Onset of the High Stand ST (HST)

2 Major transgression (MTS)

1 The Curtis Sea starts to transgress the study area (TST)

Shadscale Mesa (SM) (See Fig. 4H)

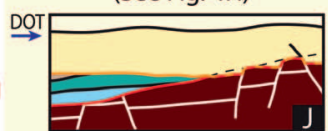

J. Major transgressive surface, tidal ravinement, and fault reactivation

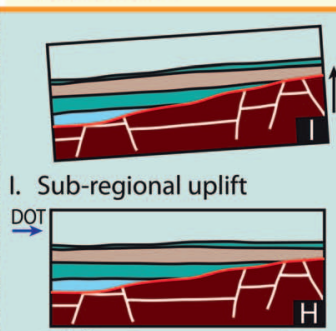

H. Tidal ravinement, and passive marine infill (lower Curtis)

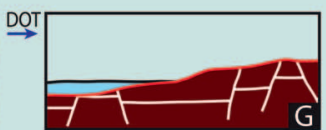

G. Strong ravinement as the Curtis sea transgression start

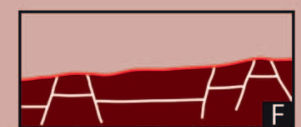

F. Ongoing eolian deflation

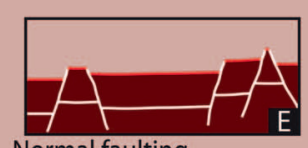

E. Normal faulting

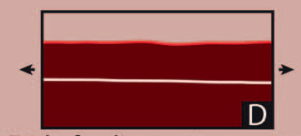

D. End of eolian system construction phase, onset of eolian deflation
Big Pinto Mesa (BPM)

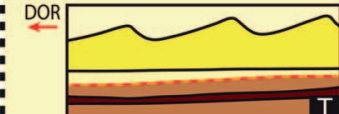

Hanksville Airport (HKA) : T. Start of eolian system con(See Fig. 4L) struction phase t3-HSST

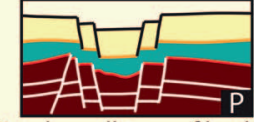

P. Circular collapse of both formations

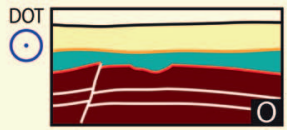

O. Major transgressive surface, and tidal ravinement

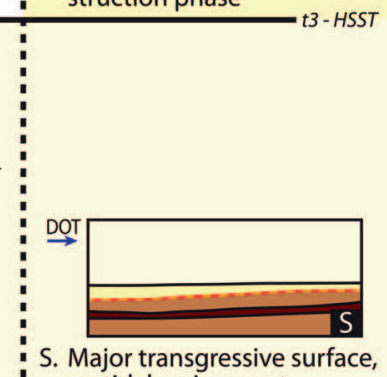

$\odot$

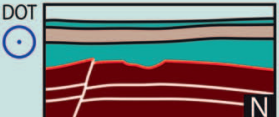

N. Passive marine infill (lower Curtis)

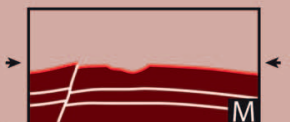

M. Local contractional folding and thrusting due to sand remobilization
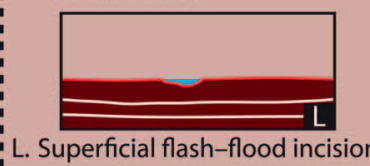

no tidal ravinement

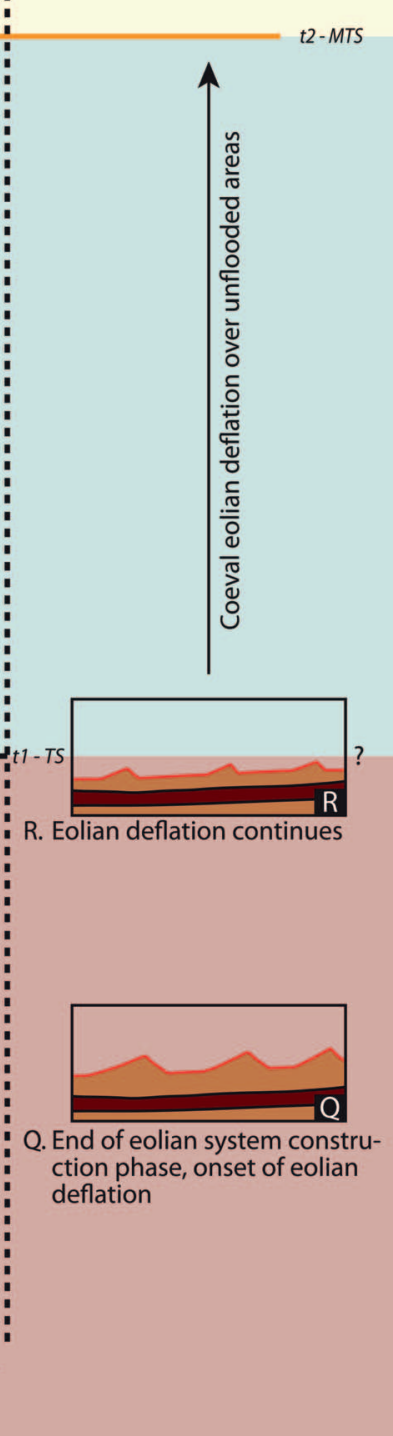

FIG. 8.-Diagrams showing when the various processes impacted the J-3 Unconformity at four selected localities. Note that the spacing between t1 (onset of the Curtis sea transgression), $\mathrm{t} 2$ (major transgression), and $\mathrm{t} 3$ (onset of the high stand systems tract) do not hold any absolute time information, but these three lines themselves do represent fixed points in time. The red background color corresponds to pre-Curtis-sea-transgression times; the green color to post-Curtis-sea-transgression and lower Curtis times; the light yellow to post-major-transgression and middle Curtis times; and the dark yellow to the highstand systems tract. Each window is approximately $100-150$ m wide and 10$15 \mathrm{~m}$ tall. 
Processes:

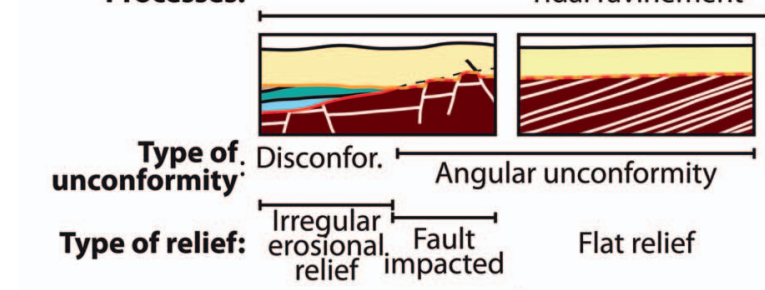

$\begin{aligned} \text { Lithology below. } & \text { lower Curtis } \\ \text { the MTS } & \text { earthy facies }\end{aligned}$
Tidal ravinement

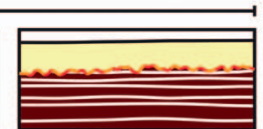

Disconformity

Irregular erosive relief
Eolian deflation (Tidal ravinement ?)

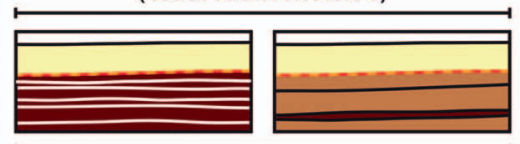

Paraconformity
Tidal ravinement (eolian deflation?)

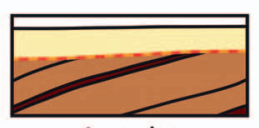

Angular unconformity

FIG. 9.-Diagram illustrating the non-uniqueness of the relief generated by the major transgression, highlighting the complexity existing in the system, between the processes involved, the types of unconformity and the types of relief they generated, as well as the underlying reworked lithology.

Wagoner et al. 1990; Catuneau et al. 2009). However, no erosional unconformity related to relative sea-level fall exists in the San Rafael Group. Therefore, no sequence boundaries sensu Mitchum et al. (1977) exists, with the exception of the J-5 Unconformity, which caps the San Rafael Group, resulting from a relative base-level fall associated with the development of the Upper Jurassic megafan system of the Morrison Formation (Hintze and Kowallis 2009). As a result, the Carmel-Entrada-Curtis-Summerville interval represents an overall transgressive-to-highstand-to-transgressive-tohighstand systems-tract alternation. Following the "Exxonian" school, this interval therefore consists of two parasequence sets (Carmel-Entrada, Curtis-Summerville), separated by a composite, diachronous ravinement surface (the so-called J-3 Unconformity). However, higher-frequency relative sea-level variations were superimposed on this interval, responsible for the development of the four eolian sequences of the Entrada Sandstone (Carr-
Crabaugh and Kocurek 1998; Mountney 2006), and the five eolian sequences of the Moab Member of the Curtis Formation (Zuchuat et al. 2019). Each of the supersurfaces bounding these eolian sequences formed during transgressive episodes (Kocurek 1988; Crabaugh and Kocurek 1993; Carr-Crabaugh and Kocurek 1998; Mountney 2012; Mountney 2006; Rodríguez-López et al. 2013), and are classified as higher-order sequence boundaries. These eolian sequence boundaries are considered to correlate to identifiable flooding and ravinement surfaces in their respective contemporaneous shallow-marine realms. These supersurfaces and correlative flooding and ravinement surfaces should be therefore utilized as sequence boundaries in arid and continental to shallow-marine settings. Consequently, the J-3 Unconformity represents one of the major, composite, heterochronous, and diachronous sequence boundaries of the San Rafael Group, together with the flooding surface that defines the base of the Carmel Formation (Fig. 2C).

\section{A. Schematic basin evolution during a relative sea-level rise}

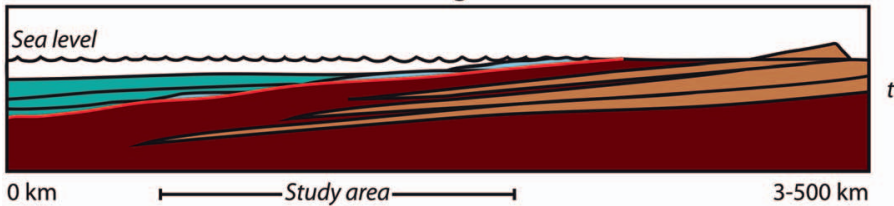

B. Time groups and diachronous ravinement-surface development

$$
\text { - Ravinement surface }
$$

As the sediment budget available for eolian construction diminishes due to the RSL rise, the eolian system remains active, but it adapts to the new conditions, downsizes and migrates towards a more suitable environment.

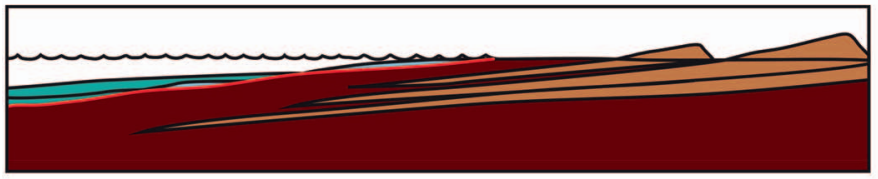

t2

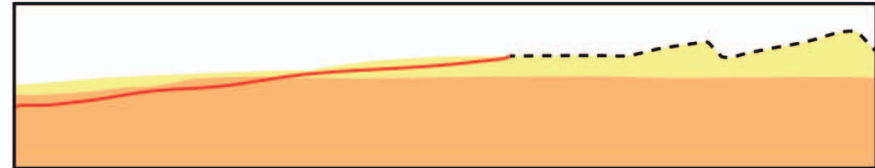

As the relative sea level (RSL) rises, the marine currents can locally erode into the previously deposited eolian deposits, generating a ravinement surface between the two coexisting systems.

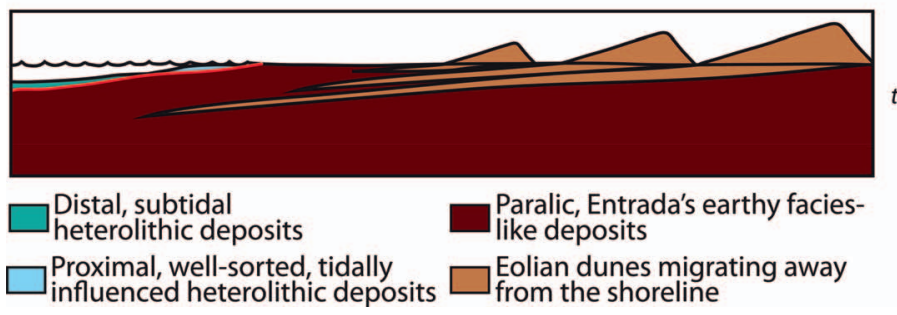

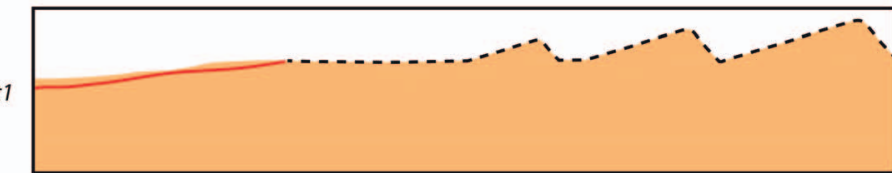

Sediments accumulated between $t 2$ and $t 3$

Sediments accumulated between $t 1$ and $t 2$

Sediments accumulated until $t 1$

FIG. 10.-A) Model showing the evolution, over time, of an eolian system, adjacent to and coexisting with a subaqueous domain. The whole composite system undergoes a progressive climatic change towards a more humid period and a constant relative sea-level rise (RSL) and is fed by a steady sediment supply. B) The coexisting eolian and subaqueous deposits are grouped according to their age. The orange color represents the accumulated sediment until t1, the yellow color the accumulated sediments between

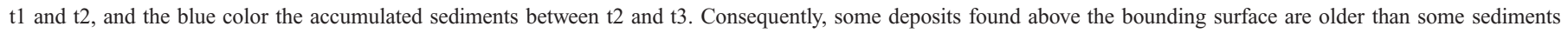

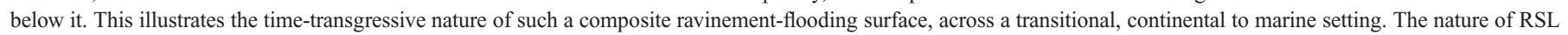
rise is irrelevant to the model, and the vertical scale is not representative of the reality. 


\section{Subsurface Implications of Heterochronous and Composite "Unconformities"}

Subsurface analyses often suffer a scarcity of available data, as well as resolution limitations, in comparison with field-based studies. Such constraints can be partially counteracted if unconformities are not regarded as monogenetic and isochronous surfaces, but rather considered as subseismic (i) non-unique, (ii) composite, and (iii) heterochronous features.

Burgess and Prince (2015) discussed the significance of non-unique stratal geometries and the importance of considering several models to assess stratigraphic signature, rather than using a singular sequence stratigraphic framework. A single stratigraphic surface geometry and/or relief can be generated by different processes. As an example, the J-3 as a paraconformity was impacted partially by both eolian deflation and tidal ravinement; the concave-up J-3 surface could have been generated by hydroplastic sagging or tidal incision. The non-uniqueness concept of Burgess and Prince (2015) can be further extended to encompass the various impacts that a single process can have on a given system. For instance, as the major transgression at the base of the middle Curtis occurred, tidal ravinement forces generated a range of reliefs in the J-3 Unconformity: angular unconformity, paraconformity, and disconformity (Fig. 9). Hence, as a single type of geometry can be attributed to several processes, one single process can generate multiple types of relief. Studies on regional unconformities should therefore carefully consider this before proposing unique interpretations, especially when analyzing strata contacts based solely on geometrical attributes at one single location.

However, the non-unique character of several surfaces can sometimes lead to chronostratigraphic challenges. In the case of the J-3 Unconformity, some of the resulting geometries could have been equally generated by different, singular, and time-dependent processes. For instance, concave-up geometries could have resulted from pre-transgressional hydroplastic minisags (Fig. $7 \mathrm{~N}$ ), or they might have been generated by funneled and erosive tidal currents, as available accommodation diminished (Fig. 7E). These two interpretations would lead to significantly different basin reconstructions. Furthermore, even if the correct process was assumed, uncertainties remain with regard to timing. If such an incision occurred before the or at an early stage of the system development, the infill would potentially be uncompartmented (Fig. 11A). If it occurred at a later stage, the system could have cannibalized and compartmentalized its intraformational substratum as well as the underlying sedimentary unit (Fig. 11B). The positive or negative impact of connected and laterally extensive, or compartmented sedimentary bodies on the system depends on: (i) the (sealing or permeable) nature of the infill and the underlying substratum; (ii) the purpose(s) the system is considered for; and (iii) the scale of the study. The timing of the two scenarios described above (Fig. 11A, B), and the timespan existing between them, could also imply a differential diagenetic imprint over the system. As a result, before attributing any chronostratigraphic character to the resulting bounding surface, it must be correctly reconstructed, regarding both its composite nature and its heterochronous and diachronous history.

The transgressive-regressive context of an incision like the J-3 Unconformity (Fig. 11) would have further impacted the redistribution of eroded material in the basin due to the low-gradient conditions, in which minor changes in available accommodation would have significantly moved the facies and processes belt in a 3D space (Midtkandal and Nystuen 2009; Zuchuat et al. 2018). If the incision occurred during a transgressive phase, remobilized sediments were likely redistributed towards the shoreline, whereas, if the incision occurred during a regressive phase, then sediments were redistributed away from the shoreline, towards the deeper part of the basin. This might lead to overestimation or underestimation of sediment delivery and storage in the system, as well as erroneous models of basin dynamics and reservoir predictions, if stratal bounding surfaces are overlooked and/or misinterpreted, especially in lowgradient, transitional settings.

Therefore, surfaces such as the J-3 Unconformity or the North Sea Unconformity Complex (Fig. 1; Kyrkjebø et al. 2004) should be rigorously considered when reconstructing the dynamic history of regional basins, or when assessing reservoir quality and seal integrity of petroleum or $\mathrm{CO}_{2}$ plays occurring directly underneath them, or in their close vicinity. Targets located at shallower depth than such composite bounding surfaces (or potentially deep below them), can, most likely, disregard their complexity when constructing reservoir models. The spatio-temporal scale at, and the purpose for which, a system is studied ultimately dictates whether the composite, heterochronous, and diachronous nature of considered boundaries plays an important role, or if it can be disregarded without major implications for the resulting model of basin evolution. The study of the J-3 Unconformity, and analyses conducted on similar composite and amalgamated bounding surfaces, highlights how the understanding of transitional zones and their correlative sedimentary basins can be improved, independently of the basinal setting and scale (Kyrkjebø et al. 2004; Sattler et al. 2005; Al-Hinaai and Redfern 2014; Leszczyński and Nemec 2015; Miall 2016; Gani 2017).

\section{CONCLUSIONS}

Eight types of relief are identified along the J-3 Unconformity, separating the Entrada Sandstone from the Curtis Formation in eastcentral Utah; these can be subdivided into (i) angular unconformity, (ii) paraconformity, (iii) steep incisions, (iv) undulating relief, (v) irregular relief, including fault-plane- and erosion-related relief irregularities, (vi) circular collapsed structures, (vii) sedimentary loading, and (viii) hydroplastic sagging. Erosive processes, including eolian deflation, incision linked to flash floods, tidal ravinement during transgressive phases, and funneling of tidal currents during regressions have generated angular unconformities, paraconformities, undulating surfaces, steep incisions, and irregular relief. Deformation-related processes are responsible for the

FIG. 11.-Cartoon illustrating four different interpreted scenarios of a limited dataset, which consists of a 2D seismic line and a core. In this hypothetical case, Reservoir A and Reservoir B display the best reservoir quality, and are separated by a sealing unit. Reservoir C is characterized by lower porosity-permeability values in comparison to Reservoirs A and B. Scenario A: t1: Reservoir A, and the sealing unit are undisturbed. 2 : the transgression is accompanied by a narrow incision of the seal unit as Reservoir $\mathrm{B}$ is being deposited, and the faulting of the strata occurs simultaneously. $\mathrm{t} 3$ : a regressive phase is accompanied by the deposition of Reservoir C. Consequences: Reservoir B is not compartmentalized, and is potentially well connected to Reservoir A, depending on the fault properties. As the sediments are eroded during a transgression, they are redistributed towards the shoreline. Scenario B: t1: Reservoir A and the sealing unit are undisturbed. $\mathrm{t} 2$ : the transgression is accompanied by the deposition of Reservoir B, and the faulting of the strata occurs simultaneously. $\mathrm{t} 3$ : a regressive phase leads to the development of a narrow incision, and is accompanied by the deposition of Reservoir C. Consequences: Reservoir B is compartmentalized, but it is potentially well connected to Reservoir A, depending on the fault properties. As the sediments are eroded during a regression, they are redistributed away from the shoreline, towards the basin. Scenario C: $\mathrm{t} 1$ : Reservoir A and the sealing unit are already faulted. $\mathrm{t} 2$ : the transgression is accompanied by a narrow incision of the seal unit as Reservoir B is being deposited. $\mathrm{t} 3$ : a regressive phase is accompanied by the deposition of Reservoir C. Consequences: Reservoir B is not compartmentalized and is not connected to Reservoir A. As the sediments are eroded during a transgression, they are redistributed towards the shoreline. Scenario D: $\mathrm{t}$ : Reservoir A and the sealing unit are already faulted. $\mathrm{t} 2$ : the transgression is accompanied by the deposition of Reservoir B. $\mathrm{t}$ : a regressive phase leads to the development of a narrow incision, and is accompanied by the deposition of Reservoir C. Consequences: Reservoir B not compartmentalized and is not connected to Reservoir A. As the sediments are eroded during a regression, they are redistributed away from the shoreline, towards the basin. 
A. Dataset

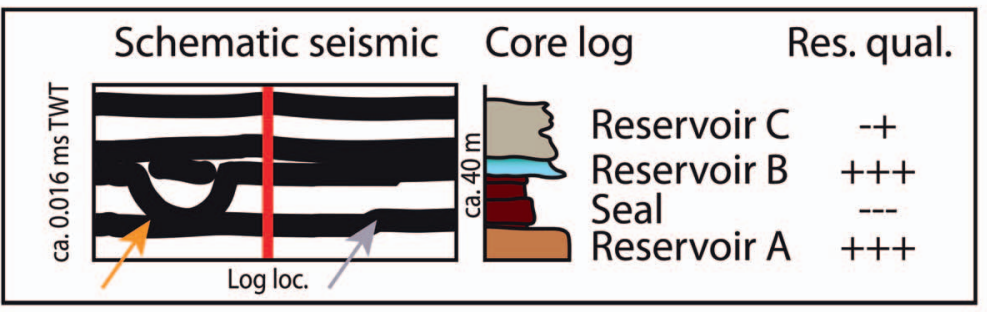

Observations:

1. concave-up reflactor

2. small fault

B. Geological models

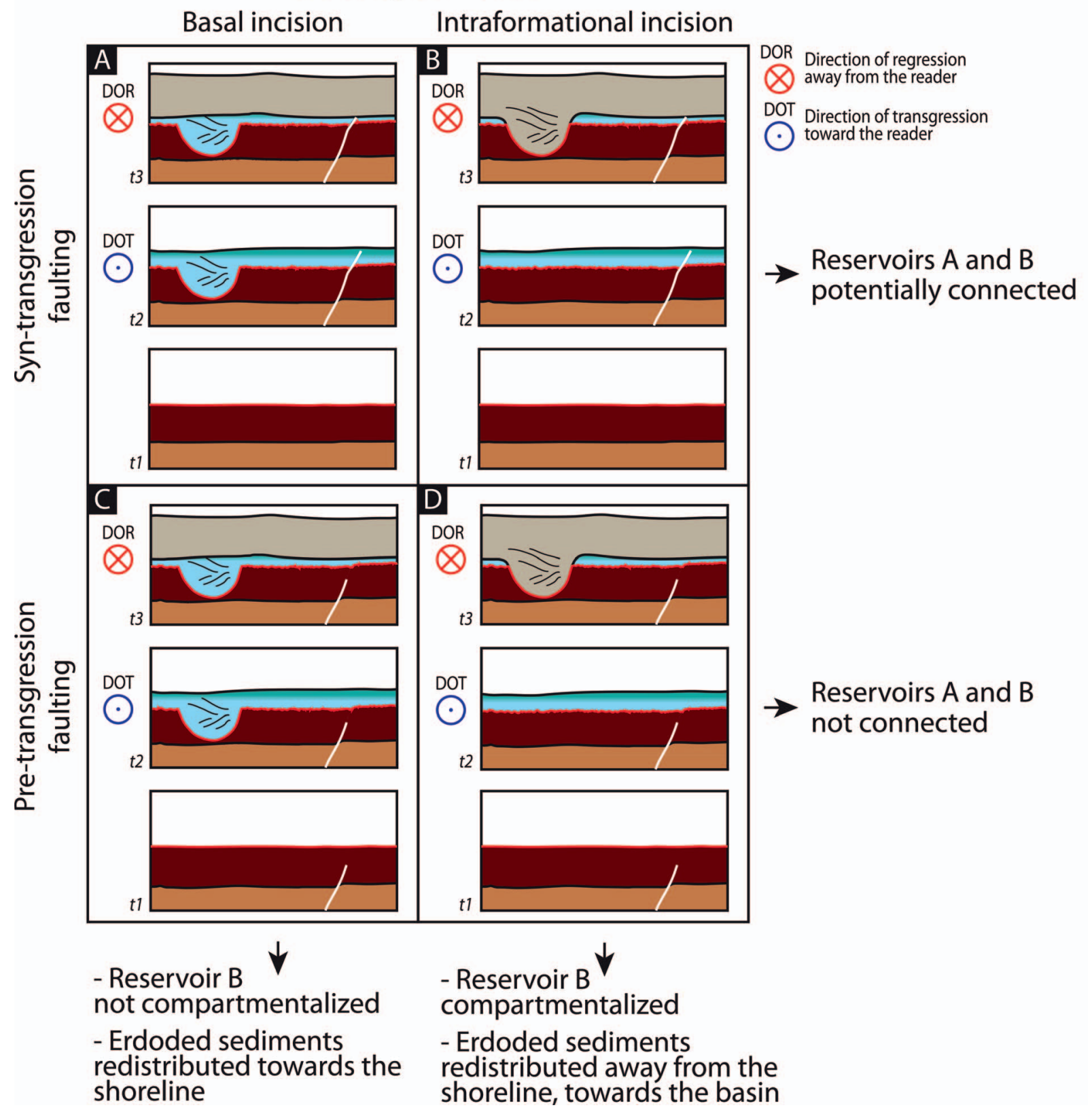


development of ring-fault collapsed structures, hydroplastic mini-sags, and loading structures. Erosion-related features are common and widespread, whereas deformation-related features are rare and localized.

The development of the J-3 Unconformity has to be considered within a four-dimensional frame, in which each individual processes interacted with the bounding surface through both space and time. The impact of a single process in the J-3 Unconformity is spatio-temporally non-unique. Therefore, the composite and highly heterohronous nature of such a surface implies that it cannot be regarded as a genuine time barrier, and thus, as an unconformity sensu stricto. It is proposed that the concept of unconformity should emphasize the processes involved in the genesis of such a surface, and the environmental changes associated with them, while applying the time-barrier aspect only at local scales.

As eolian sequence boundaries (supersurfaces) form during transgressive episodes, it is proposed to use these supersurfaces and correlative flooding and ravinement surfaces as sequence boundaries in arid and continental to shallow-marine settings. The diachroneity of ravinement surfaces can be extended from the shelf into a transitional basinal setting between continental eolian and shallow marine deposits. Studies of these transitional settings, both at outcrop and in the subsurface, should therefore take account of the composite nature of such bounding surfaces, and take care when attributing them a chronostratigraphic character.

Although this work demonstrates that several contacts described as unconformities might be in fact composite and time-transgressive surfaces, their use in basin reconstructions may still be appropriate depending on the research focus and the scale of the studies. In these cases, accurate dating would dictate whether the heterochronous and diachronous nature of the considered boundary can be consciously disregarded without major implications for both timing and prediction of sediment delivery and storage in basin-evolution models.

\section{SUPPLEMENTAL MATERIAL}

Supplemental material is available from the SEPM Data Archive: https:// www.sepm.org/supplemental-materials.

\section{ACKNOWLEDGMENTS}

We would like to thank the Norwegian Research Council for their awarded COPASS grant 244049. Acknowledgements are to be extended to Dr. Mark Mulrooney, Anna van Yperen, Arve Sleveland, and Ole Rabbel for their assistance and fruitful comments, which enhanced the quality of this work. Dr. Andrew Madof, Prof. Paul McCarthy, Prof. Gary Weissmann, and Prof. John B. Southard are gratefully acknowledged for their constructive observations and remarks on an earlier version of this manuscript.

\section{REFERENCES}

Al-HinaAi, J., And Redfern, J., 2014, The late Carboniferous basal Grant Group unconformity, Canning Basin, Australia: a complex surface recording glacial tectonic and halotectonic processes: Australian Journal of Earth Sciences, v. 61, p. 703-717.

ANDERSON, O.J., AND LuCAS, S.G., 1994, Middle Jurassic stratigraphy, sedimentation and paleogeography in the southern Colorado Plateau and southern High Plains, in Caputo, M.V., Peterson, J.A., and Franczyk, K.J., eds., Mesozoic Systems of the Rocky Mountain Region, USA: SEPM, Rocky Mountain Section, p. 299-314.

ANDERSON, T.H., 2015, Jurassic (170-150 Ma) bathe tracks of a continental-scale fault, the Mexico-Alaska megashear, from the Gulf of Mexico to Alaska, in Anderson, T.H., Didenko, A.N., Johnson, C.L., Khanchuk, A.I., and MacDonald, J.H., eds., Late Jurassic margin of Laurasia: a record of faulting accommodating plate rotation: Geological Society of America, Special Paper 513, p. 107-188.

Assallay, A.M., Rogers, C.D.F., and SMalley, I.J., 1997, Formation and collapse of metastable particle packings and open structures in loess deposits: Engineering Geology, v. 48 , p. $101-115$.

BARRELL, J., 1917, Rhythms and the measurements of geologic time: Geological Society of America, Bulletin, v. 28, p. 745-904.

BJerrum, C.J., AND Dorsey, R.J., 1995, Tectonic controls on deposition of Middle Jurassic strata in a retroarc foreland basin, Utah-Idaho trough, western interior, United States Tectonics, v. 14, p. 962-978.
BLACKWELDER, E., 1909, The valuation of unconformities: The Journal of Geology, v. 17, p. 289-299.

Blakey, R.C., 1994, Paleogeographic and tectonic controls on some Lower and Middle Jurassic erg deposits, Colorado Plateau, in Caputo, M.V., Peterson, J.A., and Franczyk, K.J., eds., Mesozoic Systems of the Rocky Mountain Region, USA: SEPM, Rocky Mountain Section, p. 273-298.

Blakey, R.C., 2019, Pennsylvanian-Jurassic sedimentary basins of the Colorado Plateau and southern Rocky Mountains, in Miall, A.D., ed., Sedimentary Basins of the World: Amsterdam, Elsevier, p. 245-296.

Blum, M., Martin, J., Milliken, K., and Garvin, M., 2013, Paleovalley systems: insights from Quaternary analogs and experiments: Earth-Science Reviews, v. 116, p. 128-169. Bonaventura, X., Sima, A.A., Feixas, M., Buckley, S.J., Sbert, M., and Howell, J.A., 2017, Information measures for terrain visualization: Computers \& Geosciences, v. 99, p. 9-18.

Brenner, R.L., and Peterson, J.A., 1994, Jurassic sedimentary history of the northern portion of the Western Interior Seaway, USA, in Caputo, M.V., Peterson, J.A., and Franczyk, K.J., eds., Mesozoic Systems of the Rocky Mountain Region, USA: SEPM, Rocky Mountain Section, p. 233-272.

Buckley, S., Ringdal, K., Dolva, B., Naumann, N., and Kurz, T., 2017, LiME: 3D visualisation and interpretation of virtual geoscience models: European Geosciences Union, General Assembly, Conference Abstracts, v. 19, p. 15952.

Bump, A.P., AND DAVIS, G.H., 2003, Late Cretaceous-early Tertiary Laramide deformation of the northern Colorado Plateau, Utah and Colorado: Journal of Structural Geology, v. 25, p. 421-440.

Burgess, P.M., And Prince, G.D., 2015, Non-unique stratal geometries: implications for sequence stratigraphic interpretations: Basin Research, v. 27, p. 351-365.

Caputo, M.V., AND Pryor, W.A., 1991, Middle Jurassic tide- and wave-influenced coastal facies and paleography, upper San Rafael Group, east-central Utah, in Chidsey, T.C., Jr., ed., Geology of East-Central Utah: Utah Geological Association, v. 19, p. 9-27.

Carr-Crabaugh, M., and Kocurek, G., 1998, Continental sequence stratigraphy of a wet eolian system: a key to relative sea-level change, in Stanley, K.W., and McCabe, P.J., eds., Relative Role of Eustasy, Climate, and Tectonics in Continental Rocks: SEPM, Special Publication 59, p. 213-228.

Catuneanu, O., Abreu, V., Bhattacharya, J.P., Blum, M.D., Dalrymple, R.W., Eriksson, P.G., Fiedling, C.R., Fisher, W.L., Galloway, W.E., Gibling, M.R., Giles, K.A., Holbrook, J.M., Jordan, R., Kendall, C.G.St.C., Macurda, B., Martinsen, O.J., Miall, A.D., Neal, J.E., Nummedal, D., Pomar, L., Posamentier, H.W., Pratt, B.R., Sarg, J.F., Shanley, K.W., Steel, R.J., Strasser, A., Tucker, M.E., And Winker, C., 2009, Towards the standardization of sequence stratigraphy: Earth-Science Reviews, v. 92, p. 1-33.

Crabaugh, M., and Kocurek, G., 1993, Entrada Sandstone: an example of a wet aeolian system, in in Pye, K., ed., The Dynamics and Environmental Context of Aeolian Sedimentary Systems: Geological Society of London, Special Publication 72, p. 103126.

Dickinson, W.R., 2018, Tectonosedimentary Relations of Pennsylvanian to Jurassic Strata on the Colorado Plateau: Geological Society of America, Special Paper 533, 184 p.

Dickinson, W.R., AND GeHrels, G.E., 2009, U-Pb ages of detrital zircons in Jurassic eolian and associated sandstones of the Colorado Plateau: evidence for transcontinental dispersal and intraregional recycling of sediment: Geological Society of America, Bulletin, v. 121, p. 408-433.

Dickinson, W.R., And Gehrels, G.E., 2010, Synoptic record in space and time of provenance relations for Mesozoic strata in south-central Utah from U-Pb ages of detrital zircons, in Carney, S.M., Tabet, D.E., and Johnson, C.L., eds., Geology of South-Central Utah: Utah Geological Association, Publication 39, p. 178-193.

DoelLing, H.H., 2001, Geologic map of the Moab and eastern part of the San Rafael Desert $30^{\prime} \times 60^{\prime}$ quadrangles, Grand and Emery Counties, Utah, and Mesa County, Colorado: Utah Geological Survey, Map 180, 3 plates, scale 1:100,000.

Doelling, H.H., Kuehne, P.A., Willis, G.C., And Ehler, J.B., 2015, Geologic map of the San Rafael Desert $30^{\prime} \times 60^{\prime}$ quadrangle, Emery and Grand Counties, Utah: Utah Geological Survey, Map 267DM, scale 1:62,500.

Eschner, T.B., AND Kocurek, G., 1988, Origins of relief along contacts between eolian sandstones and overlying marine strata: American Association of Petroleum Geologists, Bulletin, v. 72, p. 932-943.

GANI, M.R., 2017, Mismatch between time surface and stratal surface in stratigraphy: Journal of Sedimentary Research, v. 87, p. 1226-1234.

Gilluly, J., AND ReEside, J.B., JR., 1928, Sedimentary rocks of the San Rafael Swell and some adjacent areas in eastern Utah: U.S. Geological Survey, Professional Paper 150-D, p. $61-110$.

Gudmundsson, A., 2007, Conceptual and numerical models of ring-fault formation: Journal of Volcanology and Geothermal Research, v. 164, p. 142-160.

Helland-Hansen, W., and Martinsen, O.J., 1996, Shoreline trajectories and sequences; description of variable depositional-dip scenarios: Journal of Sedimentary Research, v. 66, p. $670-688$.

Heyman, O., 1983, Distribution and structural geometry of faults and folds along the northwestern Uncompahgre Uplift, western Colorado and eastern Utah, in Averett, W., ed., Northern Paradox Basin-Uncompahgre Uplift: Grand Junction, Colorado, Grand Junction Geological Society, p. 45-57.

HintZe, L.F., 1980, Geologic map of Utah: Utah Geological and Mineral Survey, scale $1: 250,000,2$ sheets. 
Hintze, L.F., And Kowallis, B.J., 2009, Geologic history of Utah: Provo, Utah, Brigham Young University Studies Special Publication 9, 225 p.

Hodgson, D.M., Kane, I.A., Flint, S.S., Brunt, R.L., and Ortiz-Karpf, A., 2016, Timetransgressive confinement on the slope and the progradation of basin-floor fans: implications for the sequence stratigraphy of deep-water deposits: Journal of Sedimentary Research, v. 86, p. 73-86.

Holbrook, J.M., AND Bhattacharya, J.P., 2012, Reappraisal of the sequence boundary in time and space: case and considerations for an SU (subaerial unconformity) that is not a sediment bypass surface, a time barrier, or an unconformity: Earth-Science Reviews, v. 113 , p. 271-302.

Hutton, J., 1788, Theory of the Earth, or an Investigation of the Laws observable in the Composition, Dissolution, and Restoration of Land upon the Globe: Royal Society of Edinburgh, Earth and Environmental Science, Transactions 1, p. 209-304.

IMLAY, R.W., 1952, Marine origin of Preuss sandstone of Idaho, Wyoming, and Utah: American Association of Petroleum Geologists, Bulletin, v. 36, p. 1735-1753.

KocUReK, G., 1988, First-order and super bounding surfaces in eolian sequences: bounding surfaces revisited: Sedimentary Geology, v. 56, p. 193-206.

Kocurek, G., Martindale, R.C., Day, M., Goudge, T.A., Kerans, C., HassenruckGudipati, H.J., Mason, J., Cardenas, B.T., Petersen, E., Mohrig, D., Aylward, D.S. Hughes, C.M., AND Nazworth, C.M., 2018, Antecedent aeolian dune topographic control on carbonate and evaporite facies: Middle Jurassic Todilto Member, Wanakah Formation, Ghost Ranch, New Mexico, USA: Sedimentology, v. 66, p. 808-837.

KreisA, R.D., AND Moiola, R.J., 1986, Sigmoidal tidal bundles and other tide-generated sedimentary structures of the Curtis Formation, Utah: Geological Society of America, Bulletin, v. 97, p. 381-387.

Kvale, E.P., 2012, Tidal constituents of modern and ancient tidal rhythmites: criteria for recognition and analyses, in Davis, R.A., Jr., and Dalrymple, R.W., eds., Principles of Tidal Sedimentology: Dordrecht, Springer Science and Business Media, p. 1-17.

Kyrkjebø, R., Gabrielsen, R.H., and Faleide, J.I., 2004, Unconformities related to the Jurassic-Cretaceous synrift-post-rift transition of the northern North Sea: Geological Society of London, Journal, v. 161, p. 1-17.

LeszczyŃSKI, S., AND NeMEC, W., 2015, Dynamic stratigraphy of composite peripheral unconformity in a foredeep basin: Sedimentology, v. 62, p. 645-680.

Li, P., Vanapalli, S., AND Li, T., 2016, Review of collapse triggering mechanism of collapsible soils due to wetting: Journal of Rock Mechanics and Geotechnical Engineering, v. 8, p. 256-274.

LuCAS, S.G., 2014, Lithostratigraphy of the Jurassic San Rafael Group from Bluff to the Abajo Mountains, southeastern Utah: stratigraphic relationships of the Bluff Sandstone: Volumina Jurassica, v. 12 , p. $55-68$

Madof, A.S., Harris, A.D., AND ConNell, S.D., 2016: Nearshore along-strike variability: Is the concept of the systems tract unhinged?: Geology, v. 44, p. 315-318.

Marti, J., Ablay, G.J., Redshaw, L.T., and Sparks, R.S.J., 1994, Experimental studies of collapse calderas: Geological Society of London, Journal, v. 151, p. 919-929.

Martinsen, O.J., and Helland-Hansen, W., 1995, Strike variability of clastic depositional systems: Does it matter for sequence-stratigraphic analysis?: Geology, v. 23, p. 439-442

Miall, A.D., 2016, The valuation of unconformities: Earth-Science Reviews, v. 163, p. 22 71.

MidtKandal, I., And Nystuen, J.P., 2009, Depositional architecture of a low-gradient ramp shelf in an epicontinental sea: the lower Cretaceous of Svalbard: Basin Research, v. 21, p. $655-675$.

Mitchum, R.M., JR., VAIL, P.R., AND Thompson, S., III., 1977, Seismic stratigraphy and global changes in sea level, part 2: the depositional sequence as the basic unit for stratigraphic analysis, in Payton, C.E., ed., Seismic Stratigraphy: Applications to Hydrocarbon Exploration: American Association of Petroleum Geologists, Memoir 26, p. $53-62$.

MountNey, N.P., 2006, Periodic accumulation and destruction of aeolian erg sequences in the Permian Cedar Mesa Sandstone, White Canyon, southern Utah, USA: Sedimentology, v. 53, p. 789-823.

MountNEy, N.P., 2012, A stratigraphic model to account for complexity in aeolian dune and interdune successions: Sedimentology, v. 59, p. 964-989.

Nummedal, D., AND SwIFT, D.J.P., 1987, Transgressive stratigraphy at sequence-bounding unconformities: some principles derived from Holocene and Cretaceous examples, in Nummedal, D., Pilkey, O.H., and Howard, J.D., eds., Sea-Level Fluctuation and Coastal Evolution: SEPM, Special Publication 41, p. 241-260.

OGG, J.G., OGG, G., And Gradstein, F.M., 2016, A Concise Geologic Time Scale, 2016 : Amsterdam, Elsevier, 240 p.

Oliveira, C.M., Hodgson, D.M., and Flint, S.S., 2011, Distribution of soft-sediment deformation structures in clinoform successions of the Permian Ecca Group, Karoo Basin, South Africa: Sedimentary Geology, v. 235, p. 314-330.

OwEN, G., 2003, Load structures: gravity-driven sediment mobilization in the shallow subsurface, in Van Rensbergen, P., Hillis, R.R., Maltman, A.J., and Morley, C.K., eds., Subsurface Sediment Mobilization: Geological Society of London, Special Publication 216 , p. $21-34$

Peterson, F., 1988, Stratigraphy and nomenclature of middle and upper Jurassic rocks, Western Colorado Plateau, Utah and Arizona: U.S. Geological Survey, Bulletin 1633, p. $13-56$.

Peterson, F., 1994, Sand dunes, sabkhas, streams, and shallow seas: Jurassic paleography in the southern part of the Western Interior Basin, in Caputo, M.V., Peterson, J.A., and
Franczyk, K.J., eds., Mesozoic Systems of the Rocky Mountain Region, USA: SEPM, Rocky Mountain Section, p. 233-272.

Peterson, F., And Pipiringos, G.N., 1979, Stratigraphic relations of the Navajo Sandstone to Middle Jurassic formations, southern Utah and northern Arizona: U.S. Geological Survey, Professional Paper 1035-B, p. 1-43.

Pipiringos, G.N., and O'Sullivan, R.B., 1978, Principal unconformities in Triassic and Jurassic rocks, western interior United States: a preliminary survey: U.S. Geological Survey, Professional Paper, 1035-A, p. 1-29.

Rameil, N., Immenhauser, A., Csoma, A.E., And Warrlich, G., 2012, Surfaces with a long history: the Aptian top Shu'aiba Formation unconformity, Sultanate of Oman: Sedimentology, v. 59, p. 212-248.

Rodríguez-López, J.P., Meléndez, N., De Boer, P.L., Soria, A.R., And Liesa, C.L., 2013, Spatial variability of multi-controlled aeolian supersurfaces in central-erg and marineerg-margin systems: Aeolian Research, v. 11, p. 141-154.

Sattler, U., Immenhauser, A., Hillgärtner, H., And Esteban, M., 2005, Characterization, lateral variability and lateral extent of discontinuity surfaces on a carbonate platform (Barremian to Lower Aptian, Oman): Sedimentology, v. 52, p. 339-361.

Shanmugam, G., 1988, Origin, recognition, and importance of erosional unconformities in sedimentary basins, in Kleinspehn, K.L., and Paola, C., eds., New Perspectives in Basin Analysis: New York, Springer, Frontiers in Sedimentary Geology, p. 83-108.

Sprinkel, D.A., Doelling, H.H., Kowallis, B.J., WaAnders, G., and Kuehne, P.A., 2011, Early results of a study of Middle Jurassic strata in the Sevier fold and thrust belt, Utah, in Sprinkel, D.A., Yonkee, W.A., and Chidsey, T.C., Jr., eds., Sevier Thrust Belt: Northern and Central Utah and Adjacent Areas: Utah Geological Association, Publication 40, p. 151-172.

STENo, N., 1669, De solido intra solidum naturaliter contento dissertationis prodromus

Thorman, C.H., 2011, The Elko orogeny: a major tectonic event in eastern Nevadawestern Utah, in Sprinkel, D.A., Yonkee, W.A., and Chidsey, T.C., Jr., eds., Sevier Thrust Belt: Northern and Central Utah and Adjacent Areas: Utah Geological Association, Publication 40, p. 117-129.

VAil, P.R., Mitchum, R.M., JR., And Thompson, S., III, 1977, Seismic stratigraphy and global changes of sea level, Part 4: global cycles of relative changes of sea level, in Payton, C.E., ed., Seismic Stratigraphy: Applications to Hydrocarbon Exploration: American Association of Petroleum Geologists, Memoir 26, p. 83-97.

Van Wagoner, J.C., Mitchum, R.M., JR., Campion, K.M., and Rahmanian, V.D., 1990, Siliciclastic sequence stratigraphy in well logs, cores, and outcrops: American Association Petroleum Geologists, Methods in Exploration, v. 7, p. 1-55.

Van Yperen, A.E., Holbrook, J.M., Poyatos-Moré, M., and Midtkandal, I., 2019, Coalesced delta-front sheet-like sandstone bodies from highly avulsive distributary channels: the low-accommodation Mesa Rica Sandstone (Dakota Group, New Mexico, USA): Journal of Sedimentary Research, v. 89, p. 654-678.

WANG, P., 2012, Principles of sediment transport applicable in tidal environments, in Davis, R.A., Jr., and Dalrymple, R.W., eds., Principles of Tidal Sedimentology: Dordrecht Springer Science and Business Media, p. 19-34.

Westoby, M.J., Brasington, J., Glasser, N.F., Hambrey, M.J., and Reynolds, J.M., 2012, "Structure-from-Motion" photogrammetry: a low-cost, effective tool for geoscience applications: Geomorphology, v. 179, p. 300-314.

Wheatley, D.F., Chan, M.A., And SprinKel, D.A., 2016, Clastic pipe characteristics and distributions throughout the Colorado Plateau: implications for paleoenvironment and paleoseismic controls: Sedimentary Geology, v. 344, p. 20-33.

Wheeler, H.E., 1958, Time-stratigraphy: American Association of Petroleum Geologists, Bulletin, v. 42, p. 1047-1063.

Wilcox, W.T., AND Currie, B., 2008, Sequence Stratigraphy of the Jurassic Curtis, Summerville, and Stump formations, Eastern Utah and Northwest Colorado, in Longman, M.W., and Morgan, C.D., eds., Hydrocarbon Systems and Production in the Uinta Basin, Utah: Rocky Mountain Association of Geologists and Utah Geological Association, Publication 37, p. 9-41.

WITKIND, I.J., 1988, Geologic map of the Huntington $30^{\prime} \times 60^{\prime}$ quadrangle, Carbon, Emery, Grand, and Uintah counties, Utah: U.S. Geological Survey, Miscellaneous Investigations Series Map I-1764, scale 1:100,000.

YAnG, Y.C., Zhou, J.W., Xu, F.G., And Xing, H.G., 2016, An experimental study on the water-induced strength reduction in Zigong argillaceous siltstone with different degree of weathering: Advances in Materials Science and Engineering, v. 2016, p.1-12.

YonkeE, W.A., AND WeIL, A.B., 2015, Tectonic evolution of the Sevier and Laramide belts within the North American Cordillera orogenic system: Earth-Science Reviews, v. 150, p. 531-593.

Zuchuat, V., Sleveland, A.R.N., Sprinkel, D.A., Rimkus, A., Braathen, A., And MidTKAndal, I., 2018, New insights on the impact of tidal currents on a low-gradient, semi-enclosed, epicontinental basin: the Curtis Formation, east-central Utah, USA Geology of the Intermountain West, v. 5, p. 131-165.

Zuchuat, V., Sleveland, A.R., Pettigrew, R.P., Dodd, T.J., Clarke, S.M., Rabbel, O., and MidtKandal, I., 2019, Overprinted allocyclic processes by tidal resonance in an epicontinental basin: the Upper Jurassic Curtis Formation, east-central Utah, USA: The Depositional Record, v. 5, p. 272-305.

Received 1 August 2018; accepted 14 August 2019. 